Portland State University

PDXScholar

1988

\title{
Die Rolle der Hexe in den Märchen der Brüder Grimm und Ludwig Bechsteins
}

Karin Ulrike Herrmann

Portland State University

Follow this and additional works at: https://pdxscholar.library.pdx.edu/open_access_etds

Part of the Folklore Commons, and the German Literature Commons Let us know how access to this document benefits you.

Recommended Citation

Herrmann, Karin Ulrike, "Die Rolle der Hexe in den Märchen der Brüder Grimm und Ludwig Bechsteins" (1988). Dissertations and Theses. Paper 3815.

https://doi.org/10.15760/etd.5699

This Thesis is brought to you for free and open access. It has been accepted for inclusion in Dissertations and Theses by an authorized administrator of PDXScholar. Please contact us if we can make this document more accessible: pdxscholar@pdx.edu. 
AN ABSTRACT OF THE THESIS OF Karin UIrike Herrmann for the Master of Arts in German presented May 16, 1988.

Title: Die Rolle der Hexe in den Märchen der Brüder Grimm und Ludwig Bechsteins.

APPROVED BY MEMBERS OF THE THESIS COMMITTEE:

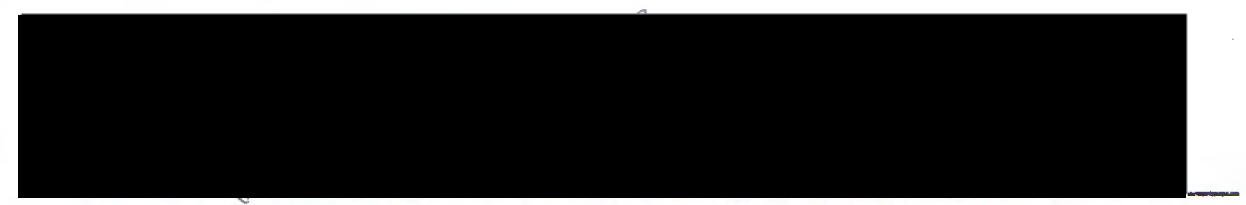

Laureen Nussbaum

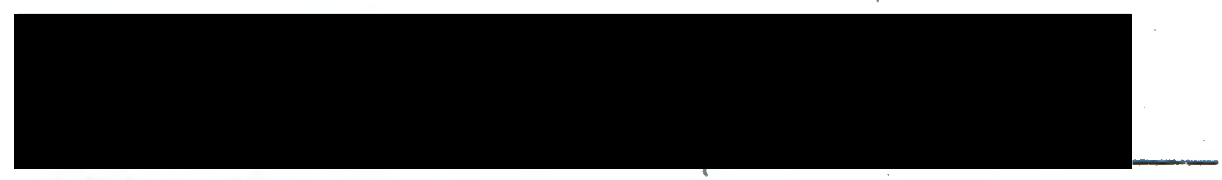

William Fischer

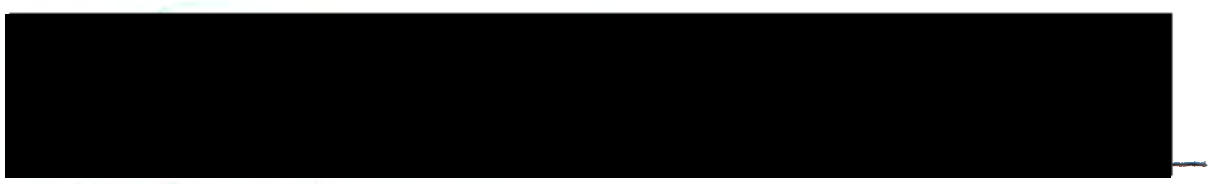

Linda Parshall

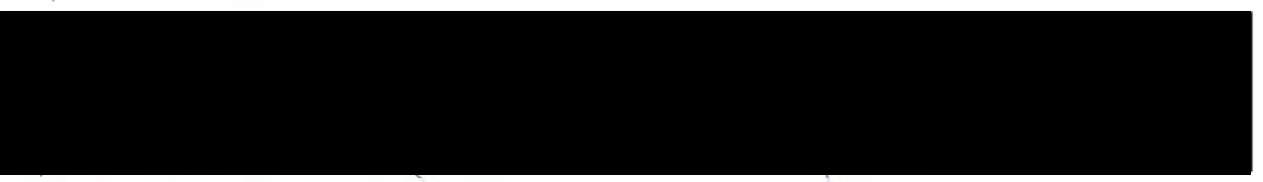

Susan Karant-Nunn

Fatry Tales have been an important part of peoples' cultural heritage since time immemorial. From a very early age on, chlldren hear storles about witches, glants, dwarfs, and magicians which make up their first 
entry into the literary world. Only recently have scholars begun to research just how much influence these stories have on children and how they might have a different impact on girls than on boys. This thesis will investigate the world of fairy tales in relation to their historical context and their differing relevance for male and female readers. I will examine the fairy tales of the brothers Grimm and of Ludwig Bechstein because these three scholars count among the most important fairy tale narrators in the German-speaking region. I will limit my examination to the witch in falry tales because of all the figures she seems to have the most impact on the audience.

The first chapter deals with various theorles about the origin of fairy tales and shows the difference in opinion between the Grimm brothers and Bechstein. It also deals with their different style of collecting fairy tale material and their different intentions in writing the tales. Finally, it looks at gender specific role differences in falry tales.

In chapter two I look at the etymology of the word 'Hexe' in order to trace the origin of the word as far back as possible and in order to find possible parallels to the concept of the witch in other languages. Then, 1 examine the appearance of the witch in pre-Christian times in comparison to the witch in the middle ages and in modern times to see whether and how her image has changed over the centuries.

Finally, in chapter three I deal with the actual roles of the witch in falry tales; of which I distinguish five:

1. the evil witch

2. the witch as stepmother

3. the witch as sorceress 
4. the witch as good and evil figure

5. the witch as wise woman/helper/good fairy

Each of these five roles is Illustrated with an example by making text comparisons between the Ölenberger Handschrift of the Grimm brothers, the first six editions of their Kinder -und Hausmärchen and Bechstein's

Sämtliche Märchen. Then I try to show how the authors' deliberate textual changes and the various roles of witches might af fect girls differently than boys.

In the final chapter I summarize the original question of how the current image of the witch originated and whether there is a possible historical link between that image and pre-Christian historical and mythological women. I finish with the conclusion that, although the witch serves an important function in fairy tales, it is now time to emphasize her positive aspects as well as her negative sides. 
DIE ROLLE DER HEXE IN DEN MÄRCHEN DER BRÜDER GRIMM UND LUDWIG BECHSTEINS

von

KARIN ULRIKE HERRMANN

A thesis submitted in partial fulfillment of the requirements for the degree of

MASTER OF ARTS

in

GERMAN

Portland State University 
TO THE OFFICE OF GRADUATE STUDIES:

The members of the Commlttee approve the thesis of Karin Ulrike Herrmann presented May 16, 1988.

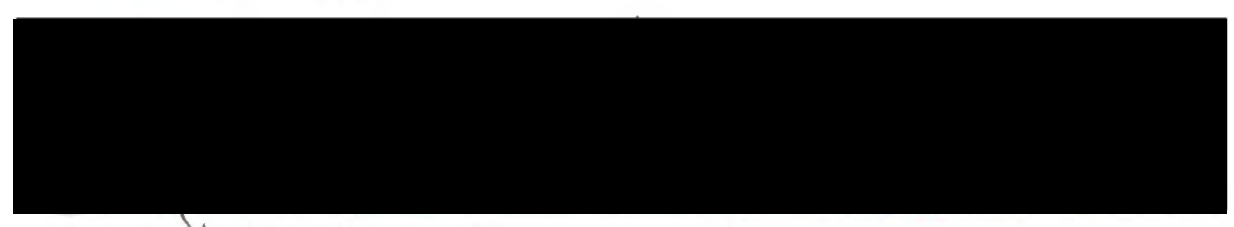

Laureèn Nussbaum, Chair

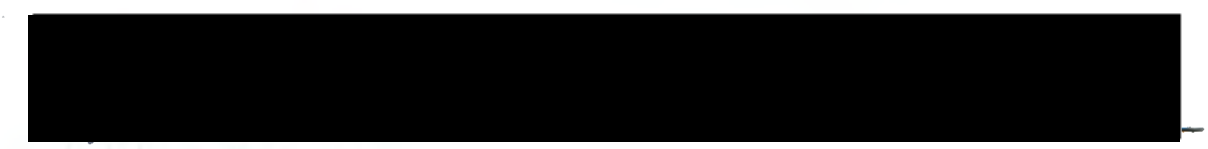

William Fischer

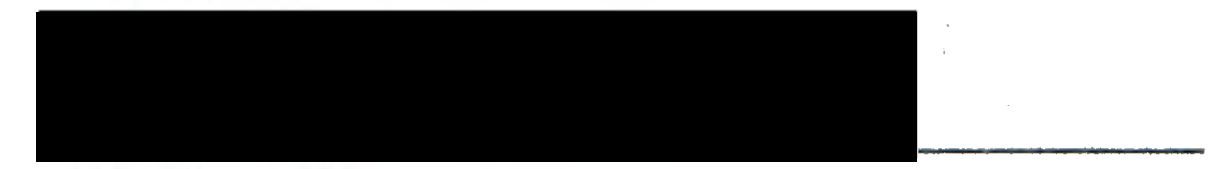

Linda Parshall

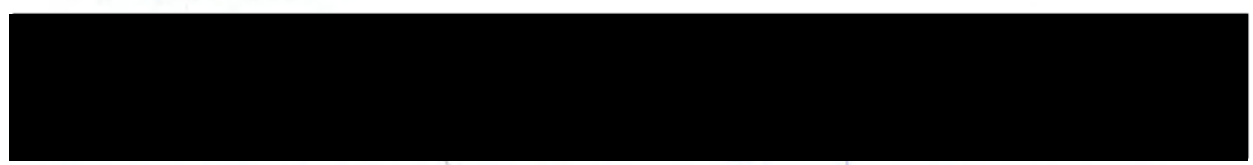

Susan Karant-Nunn

Approved:

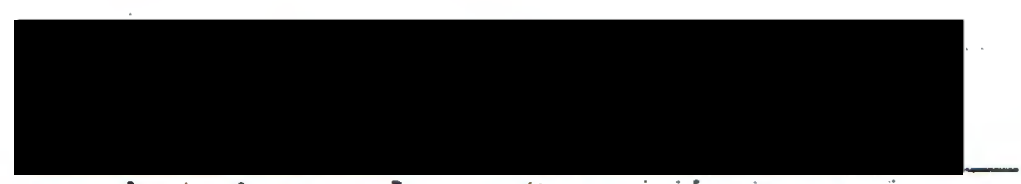

Linda Parshail, Acting Chair, Dep. of Forelgn Languages and Literature

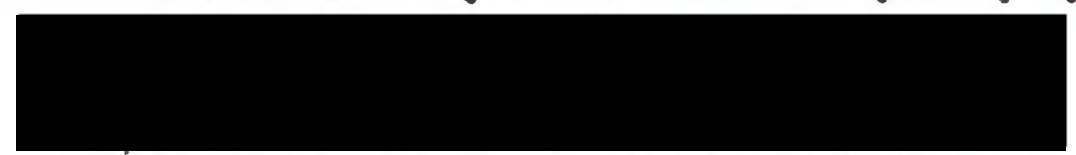

Bernard Ross, Vice Provost for Graduate Studies 


\section{ANERKENNUNG}

Folgenden fersonen bin ich zu gröBtem Darik verpflichtet: Laureen Nussbaum, meiner 'Thesenmutter', die genug Vertrauen in mich hatte, um mich e in etwas ausgefalleneres Thema wählen zu lassen, und ohne deren Ermutigung diese Arbeit nie zustande gekommen wäre; Miriam Simos, die mir mit ihren Büchern die ersten Türen zu der Welt der Hexen öffnete; Ruth Bottigheimer, deren Anregung und Hilfe mich in die richtige Richtung wiesen, und die ihr Buch gerade zur rechten Zeit veröffentlichte, um mich von neuem zu insptrieren. Gedankt sei auch den Mitgliedern der Deutschen Abteilung von Portland State University, die über die Jahre viel Geduld mit mir hatten. Und zuletzt gebührt ein Lob meinen Freunden und Bekannten für deren Unterstützung und Zuspruch. 
INHALTSANGAEE

SEITE

ANERKENNUNG

iii

KAPITEL

I EINLEITUNG.

Theorien über den Ursprung der Märchen . . . . . . . . . 7

Das Märchen als Stimme des Volkes oder des Künstlers .. . 10

Die Intentionen der Mörchenerzöhler ........... 14

Geschlechtsspezifische Rollenunterschiede ........ 24

II DIE HEXE IN DER GESCHICHTE .................. 28

Etymologie des Wortes 'Hexe' .............. 28

Dos Erscheinen des Hexenbildes in der Geschichte ...... 38

Die Hexe im Märchen ols Wornung für Kinder ........ 45

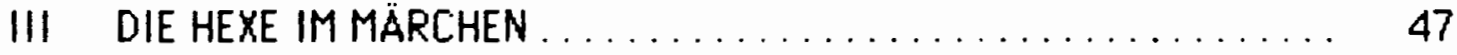

Die böse Hexe .................... 53

Die Hexe ols Stiefmutter ............... 60

Die Hexe ols Zouberin .................. 70

Die Hexe ols gute und bōse Gestalt............ 78

Die Hexe als weise Frou/Helferin/gute Fee ........ 83 
IV

SCHLUSSKAPITEL

86

Schlußfolgerung ........................... 93

BIBLIOGRAPHY ................................... 96 


\section{KAFITEL 1}

\section{EINLEITUING}

Denkt man an das literarische Ertgut eines Volkes, sa sind dargus Mytherı, Sagen, Legenden und Märchen nicht wegzudenken. Sie gehören ebenso zu dem kulturellen Erbe eines Volkes, wie die sogenarinte graße Literatur. Wohi niemand hat sich um Märchen sa verdient gemacht wie die Brüder Grimm, die Anfang des 19. Jahrhunderts begannen, Volkserzählungen zu sammeln, um sie niederzuschreiten, damit sie als Kulturgut dem deutschen Valk erhalten blieben und nicht verlorengingen. Jacot Grimm (1785-1863) und wilhelm Grimm ((1786-1859), zwei urermüdliche wissenschaftler, die sich nicht nur mit Märchen beschäitigten, sandern, netıen eirem dreitı̈rndigen Werk ütier deutsche Sagen, auch unschätzbare Farschungen auf dem Gebiet der deutschen Sproche anstellten, kreierten mit ihrer Märchensammlung, wos heute allgemein als die 'Gattung Grimm' angesehen wird. Diese Bezeichnurig geht auf Andre Jolles zurück, der diesen Begriff 1930 prägte, indem er sagte:

Man könnte beinahe sogen, ollerdings ouf die Gefohr hin, eine Kreisdefinition zu geben: ein Mörchen ist eine Erzöhlung oder eine Geschichte in der Art, wie sie die Gebrüder Grimm in ihren Kinderund Hausmärchen zusammengestellt haben. ... Und so wollen auch wir ... von der Gattung Grimm sprechen. ${ }^{1}$

1 Heirz Rölleke, Die Märchender Brüber Griman (Müncherr: Artemis Yerloy, 19a5) 36. 
Noch heute derikt marı arı die Gattung Grimri, wenn man van Märchen spricht, derin so bekannte Märchen wie sischenralied. Damräschen. Shewhtchon u. s. sind alle Märchen. die van den Gebrüdern Grimm gesammelt und fubliziert wurder.

[ieser Frazess des Sammeins tiegann für die Erüder, indem sie die Geschichten, die ihnen zugetragen wurden, zunächst handschriftlich in der sagenannten ölenterger Handschrift van 1810 festhielten. Nach erheblichen Textveränderungen und -ausschmückungen fublizierten sie 1812 die erste ¿weibändige Märcherıusgate der Kinder-und Housmärchen (KHM), geioigt von einer weiteren Veröfentlichung 1815. 1819 erschien eine erweiterte dreitı̈rodige Ausgatıe, die neben den ersten beiden Märchenbänden einen Barı mit Anmerkungen zu den Kinder-und Housmänchen enthielt. Zwischen dieser Ausgabe und der ietzten endgüitigen Fossung var 1857 erschienen nach vier weitere Editionen 1837, 1840, 1843 und 1850 , in derien weitere Veränderungen vorgenarnmen wurden. Bis heute sind die Kinder-und Housmärchen der Getirüder Grimm die beliebtesten und am weitesten vertureiteten Mörchen der Welt.

Zu Zeiten der Brüder Grimm selbst hatten sie jedach Korkurrenz van mehreren anderen Märchenerzählern, die ebenso wie sie tegannen hatten, deutsches Kulturgut zu sammeln unid niederzuschreitien. So hatte 2 . E. Jaharm August Musäus schan $178 \overline{2}-86$, dreissig Jahre var dem Erscheinen der KHHi, seine Valksmïrchen der Deutschen veröfientiichit, Benedikte Nauterts Neue Volksmörchen der Deutschen erschienen 1789-92, Albert Ludwig Grimms

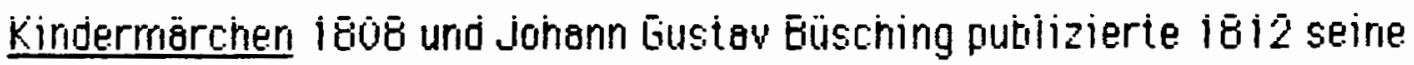
Yolkssogen, Marchen und Legenden. 
Der bei weitem erfolgreichste Konkurrent der Brüder Grimm war jedoch Ludwig Bechstein (1801-1860). Dieser unermüdliche Sammler befaßte sich zunächst hauptsächlich mit deutschen Sagen und Legendern. Mit dem Erscheinen seiner Ihüringischen Volksmärchen 1823 gab er sein Debüt a) Marchenerzäler Als er dann 1845 auf Verlangen seines Verlegers hin sein Deutsches Märchenbuch (DMB) veröffentlichte, wurde es, obwohl sich sein Material teil weise stark auf das der Märchen der K.HM stützte, populärer als die KHM der Brüder Grimm. 1856 erschien Bechisteins Neues Deutsches: Märchenbuch (NDMB), und 1857 eine abgeänderte version des DMB unter dem Titel Ludwig Bechsteins Märchenbuch. Bechste in blleb der bellebteste Märchenherausgeber des 19 Jahrhunderts, und erst nach dem ersten Weltkrieg begann seine Beliebtheit nachzulassen und von der der Brüder Grimm übertrumpft zu werden. Aus diesem Grunde werde ich mich in meiner Arbeit sowohl mit den Marchen der Brüder Grimm, als mit denen Bechsteins auseinandersetzen².

Des weiteren werde ich mich auf nur eine Gestalt der Märchen konzentrleren, da diese, wie mir scheint, eine herausragende und im Gedächtnis der Leser verhaftende Figur der Märchen ist, und bis heute womöglich den größten Einfluß auf das lesende Publikum ausübt. Es ist dles die Gestalt der Marchenhexe. Neuerdings haben sich Literaturwissenschaftler und -wissenschaft lerinnen wie Heinz Rölleke, Jack Z tpes, Ruth Bottigheimer und Sllvia Bovenschen zunehmend mit der Frage nach der

2 Die Texte. auf die ich mich stutze sind Rolieke's Die alteste Marchansammluno der Bruger Grimm (Küln-Gerif. Fondation Martín Boumer, 1975), mit der handschriftlichen Ur fassung (den Olenterger Schriften) von 1810 und dem Erstdruck von 1812 (Rölleke), die Reclamausgabe der Grimmschen Kinder - und Hausmärchen. Jacob und Wilhelm Grimm, kinder-und Hausmarctien, 5 Bände (Stuttgart, Philip Reclam Jun., 1983) (KHM) und Ludwig Bechteins, Sänilliche Marchen (Munchen. Wink ler Ver lag, 1985) (Bechstein ) 
Wichtigkeit der Märchen für ein weibliches Selbstverstandnis und den darausfolgenden Konsequenzen for dle Marchenschrelbung des 20 .

Jahrhunderst befaßt. Da dies jedoch noch ein relat iv unerschlossenes Gebiet ist, werde ich versuchen, die Rolle der Märchenhexe in Bezug auf ihren historischen Kontext und inre Relevanz für den modernen Leser und spezlell für die Leserin zu erschliessen.

Unternımmt man den Versuch, die Kinder und Hausmärchen der Brüder Grimm und die Märchen Bechsteins auf ihren Gehalt hin zu untersuchen, so muß man sehr schnell zu dem Schluß kommen, daß diese nicht isoliert von inrem sozial-historischen Umfeld entstanden sind. Man kann sie deshalb nicht einfach losgelöst von diesem Umfeld interpretieren, sondern muß sie in den historischen Rahmen einordnen, dessen Gedankengut sie tragen. Heinz Rölleke macht sich deshalb zu Recht Gedanken über die Interpretation der Grimm Märchen,

weil in vielen Märcheninterpretationsversuchen immer noch und immer wieder so verfahren wird, als könne man die KHM-Texte im Blick auf ihr vermutetes oder tatsächliches hohes Alter abgelöst von allen Bedingungen der Zeit inrer Fixierung und Verbreitung gleichsam als zeitlose oder wie voraussetzungslos vom Himmel herabgefallene Zeugnisse behandeln. Das einigermaßen komplizierte Phänomen des Grimmschen Märchens ist zu einem gewichtigen Tell durch seine Entstehungsepoche und die Persönlichkeiten seiner Schöpfer bestimmt. Daß es darüber hinaus über-oder Urzeitliches transportiert, ist damit natürlich nicht im geringsten bestritten; nur geraten die ausschließlich mit solchem Erkenntnisinteresse ansetzenden Deutungen leicht in den Bereich bloßer Spekulation. Es gilt daher wie bei der Betrachtung jedes andern sprachlichen Kunstwerks auch, die verifizierbaren facta und Realia (nach einem Lieblingsausdruck Jacob Grimms) gebührend zu berücksichtigen. 3

3 Rölleke, Die Märchen der Brüder Grimm, 26. 
Auch Ruth Bottigheimer betrachtet die Märchen der Brüder Grimm als ein historisches Dokument, obwohl sie die Wurzeln der Märchen in das 19. Jahrhundert verlegt, und nicht, wie viele andere historische Interpreten, in eine mythische urzeit.

My basic premise is that Grimms' Tales is a historical document with its roots firmly in nineteenth century Germany, an assumption that both Freudians and Jungians would dispute to a greater or lesser degree. 1 reject Freudian interpretations insofar as they assert the ahistoricity of the text; and while I do not suscribe to the Great Mother thesis of Jungian provenance, I value and sometimes utilize the painstakingly assembled collections and collations of data on which Jungian interpretations are based.4

In meinem eigenen Ansatz zur Märcheninterpretation werde ich mich einer Kombination von sozlal-historischen, mythologisch-literarischen und Jungianischen Methoden bedienen, da nur eine komplexe Betrachtungsweise der Märchen eine gültige Aussage über deren Intention und Wirkung liefern kann.

Bei der Forschung nach dem Ursprung des Hexenbildes Im Märchen ist es wichtig, zunächst einmal nachzuprüfen, welche Auffassung über den Ursprung des Märchens die Brüder Grimm im Gegensatz zu Ludwig Bechstein hatten, und zu sehen, inwlewelt diese Auffassung inre Erzähiweise beeinflusste. Zweitens ist es erforderlich, nachzuforschen, ob die Märchenerzähler bestimmte Erzählabsichten hatten, und wenn ja, wie sie diese durch bewußte oder unbewußte Manipulation der Erzähiungen zu erreichen versuchten. Und letztlich gilt es zu entscheiden, ob und inwleweit

4 Ruth Bottigheimer, preface, Grimm's Bad Girls and Bold Guvs (New Haven: Yale Univ. Press, 1987) $x$. 
sich diese Absichten auf die Rezeption der Märchen durch die Leser auswirken.

Bevor ich auf die Marchen selbst eingehen werde, werde ich versuchen, durch eine etymologische Untersuchung des Wortes 'Hexe' eine Verbindung 2 w Ischen vor-christlichen Frauengestalten und den Hexen des Hittelalters und der Neuzett herzustellen, um somit vielleicht den starken Endruck, den dle Hexe noch heute in den Marchen hervorruft, historisch erklaren zukönnen 


\section{THEORIEN ÜBER DEN URSPRUNG DES MÄRCHENS}

Über den Ursprung der Märchen gibt es verschiedene Theorien. Die wichtigsten davon lassen sich in drel Kategorlen zusammenfasseri, die als junglanisch, sozial-historisch und mythologisch-literarisch unterschieden werden können. Da ist zuriächst elrmal dle psychologisch/jungianische Theorie, die behauptet, daß die menschliche Psyche die Brutstătte der Märchen darstellt, und daß Märchen abstrakte Emotionen und psychische Vorgănge in konkrete Bilder und Handlungen übersetzen. Vertreter dieser Theorie sind Jung, Freud, Bettelheim und Lüthi, die sich allesamt hauptsächlich mit der Auswirkung des Marchens auf die Leser, insbesondere Kinder, befassen Das Hauptproblem dieser Theorie ist, daß sie äussere Einflüße, wle z. B. Sozlalisierung, vollig zu ignorieren scheint und Märchenmotive isoliert voneinander und in einem ahistorischen Kontext behandelt.

Eine weltere Theorie ist die sozlal-historische Migrationstheorie, deren Hauptyertreter Theodor Benfey war, und der auch Ludwig Bechstein anhing. Diese Theorle geht davon aus, daß alle Märchen, Ja sogar alle Sagen und Legenden, einen einzigen geographischen Ursprung haben, der das Material für alle weiteren Erzänlungen lieferte. Wăhrend der Verbreitung dieses Urmaterials durch mündliche und schriftliche Überlieferungen entstanden zahlreiche Varianten in anderen Gegenden. Der ursprüngliche 
Innalt und die Struktur der Erzänlungen blieb jedocn im wesentlichen intakt.s

Die naheliegende Frage ist hier natürlich, woher das ursprüngliche Material, die Matrix für alle weiteren Märchen, kam. Benfey verfolgte den Ursprung aller Märchen nach Indien, und es wäre interessant, jedoch hier zu weltführend, einen interdisziplinären Vergleich verschtedener Märchen anzustellen

Die dritte, mythologisch-literarische Theorie, die Märchen als ein Uberbleibsel aus alten Zeiten betrachtet, war bis zu Benfeys Erscheinen die weitverbreiteste und beliebteste der dret. Besonders die Gebrüder Grimm, sowie auch Friedrich von der Leyen, glaubten, daß die Märchen, besonders die deutschen Märchen, eine direkte Verbindung zu alten germanischen Mythologien darstellten und nur eine "abgesunkene" Form der alten Mythen seien 6

Der innere gehaltige Wert dieser Marchen ist in der Tat hoch zu schätzen, sie geben auf unsere uralte Heldendichtung ein neues und solches Licht, wie man sie nirgendher sonst-könnte zu Wege bringen $[. .$.$] in diesen Volks-märchen liegt lauter urdeutscher Mythus, den man$ für verloren gehalten?

Auch Frledrich von der Leyen schließt sich dieser Auffassung an.

Märchen und Mythos waren einmal das gleiche. Im Märchen gewannen die Wesen des volkstümlichen Glaubens und die splelerischen

5 Maria Tatar, "Folkloristic Phantasies: Grimm's Fairy Tales and Freud's Family Romance," Ealry Tales as Ways of Knowing, ed. Michael M. Metzger and Kathar ina Mommsen (Bern: Peter Lang Publishers Ltd. 1981) 75.

6 siehe James Frazer, The New Golden Bough (New York: S.G.Phillips Inc., 1959) und Heide Göltner-Abendroth, Die Göttin und ihr Heros (München: Verlag Frauenoffensive, 1980).

7 Wilhelm Grimm, in der Vorrede zum 2. KHM -Band von 1815. 
Elemente die Herrschaft ... Daneben aber, in späterer Zeit, entwickelten sich aus den Uranf angen des Glaubens und der Wirk lichkeit Märchen und Schwank als geschlossene, in sich abgerundete dichterische Gebilde. 8

und weiter behauptet er:

Die äitesten Verse im germanischen Märchen versetzten uns in die Zeit der germanischen Helden-und Götterdichtung.?

Interessant ist hier, sowohl in Bezug auf Bechsteins Hypothese eines ursprünglichen Entstehungsort aller Märchen als auch in Bezug auf Grimms Glaube an eine typisch germanische Mythologie als Ursprung der Märchen, die Frage nach dem relativ neuen Erscheinen des Hexenbildes im Märchen. Weder die alten indischen oder ägyptischen Erzählungen, noch Sagen wie z.B. die Edda oder das Nibelungenlied beinhalten die Figur der Hexe in der Gestalt, wie sie sowohl bei Bechstein, als auch in den Märchen der Brüder Grimm erscheint. Ist sie deshalb eine typisch deutsche Erfindung, und wenn ja, wann und auf welche Art und Weise entstand sie?

8 Friedrich von der Leyen. Das deutsche Märchen (Düsseldorf-Köln: Eugen Dlederichs Verlog, 1964) 33.

${ }^{9}$ ebda. 23. 
DAS MARCHEN ALS STIMME DES VOLKES ODER DES KUNSTLERS

Dies führt zu einer weiteren Frage nach der 'Stimme' des Märchens. Stammt das Märchen, wie wir es bei den Grimms und bei Bechstein finden, aus dem Munde des Volkes, oder aus der Feder des Künstlers, oder gibt es eine Wechselwirkung zwischen Volksgut und Literatur? Daß beide Seiten deutsches Kulturgut nacherzählen wollten, ist aus den Schriften Jacob und Wilhelm Grimms und Ludwig Bechsteins leicht ersichtlich. Letzterer schreibt:

Ich will acht deutsches, moglichst Volksthumliches, was das volk vorlängst aus den Erzählungen seiner Dichter in sich aufnahm und nacherzählt. Am wenigsten dient mir morgenländisches und französisches, deshalb bleiben auch Aschenbrödel, Blaubart und ogl. wahrscheinlich ganz aus meiner Sammlung; ${ }^{10}$ Während Bechstein jedoch den Erzähier der Märchen als Dichter sleht, der durchaus verändern darf, Ja sogar soll, betonen die Grimms den ursprünglichen, volkstümlichen Charakter inrer Märchen, an dem alles angeblich ur-belassen sel. im Gegensatz zu Bechstein sahen die Brüder Grimm Märchen als Naturpoesie, also als die Poesie des Volkes, das vom Volk geschaffen und vom Künstler lediglich wiedergegeben wurde und ganz strikt von der Gattung der Kunstpoesie getrennt war.

10 Brief an Storch vom 27.6.1844 in Rolf-Rüdlger Schneider, Bechsteins Deutsches Märchentuch (Wuppertal: Gesamthochsch., Fachbereich Sprach-Lit, wissenschaft, Diss. 1980) 35 
Ich [Jacob Grimm] bin fest überzeugt, daß alle Märchen unserer Sammlung ohne Ausnahme mit allen ihren Umstanden schion vor Jahrhunderten erzählt worden sind"

Maria Tatar bemerkt hierzu:

In one camp we find those who, like Arnim [and Bechstein], seek to ef face the line dividing oral traditions from literary forms; in the other, those who, like Grimm, insist on preserving the distinction between the two. 12

Mittlerwelle ist genügend bekannt, daß die Erzăhlungen, die die Brüder Grimm später als inre Kinder-und Hausmärchen veröffentlichten, innen nicht vom Volk zugetragen wurden, wle behauptet, sondern aus dem Munde und der Feder solch gebildeter Leute wie der Haxthausen Familie, der DrosteHülshoff Schwestern, Marle Hassenpflug und anderen, stammten. ${ }^{13}$ Dennoch bestanden die Brüder Grimm zu inrer Zeit auf dem volkstümlichen Ursprung und Charakter inrer Erzählungen und darauf, nur die Sprache der Erzählungen verändert zu haben, nicht aber deren Inhalt. Im Gegensatz dazu erkannte Bechstein, daß es elne Wechselwirkung zwischen Literatur und Volksmund gibt, wobei bei Bechstein "der Akzent auf seiten der Schrif tquelle liegt und dem Volksmund eine mehr nacherzählende als dichtende Funktion zukommt", während die Brüder Grimm "besonders die mündliche Überlieferung betonten." 14 Auch hier stellt sich wlederum die Frage, wie der Dichter beim

11 Johannes Bolte und George Poltyka, Anmerkunoen zu den "Kinder- und Hausmärchen", (Hildesheim: Georg Olms, 1963) 4:427.

12 Tatar, 80 .

13 stehe John Ellis, One Fairy Iale Too Many (Chicago: Univ. of Chicago Press, 1983), Heinz Rölleke, Ruth Bottigheimer U.a.

14 Schneider, 66 
Erzähien efner überlieferten Geschichte auf deren Inhalt einwirkt, und ob er nicht, gewollt oder ungewollt (und, wie ich später noch erläutern werde, be I den Grimms teilweise sogar ganz bewußt), den Inhalt mit verändert und durch das Niederschreiben bestimmte Elemente erst richtig fixiert.

Auf Seiten der Schreibweise lässt sich ein weiterer Unterschied in den Intentionen Bechsteins und der Grimms feststellen. Während die Grimms die urtümliche Sprache des Volkes so welt wie möglich erhalten wollten bis hin zum Dialekt, sah sich Bechste in hauptsächlich als Unterhalter und Erzähler. Schneider schreibt:

Aus altdeutschen Quellen will er Erzählungen in sprachlich moderner Form unter dem weitläuf igen Oberbegriff "Märchen" in Umlauf bringen und einem breiten Publikum literarisch vermittein. 15

Während die Brüder Grimm bei den Neuauf lagen von 1812, 1819 und 1857 auch immer mehr dazu übergingen, die ehemals diversen Erzählstile in einen einheitlichen sprachlichen Rahmen zu setzen, griff Bechste in zum genau entgegengesetzten Stilmittel.

Strebt die "Gattung Grimm" einem "ahistorischen St11" zu, so geht Bechstein den umgekehrten Weg, bricht die in sich abgeschlossene märchenhaf te Welt auf und tendiert zu aktuellem Erzählen. Diese Forme in vereinfachen zwar, denn auch die "Gattung Grimm" ist nicht frel von aktuellen historischen Bezügen, indes markleren sle die bei Grimm bzw. Bechste in herrschenden Tendenzen. 16

Diese Freineit des Erzählens erlaubt es Bechstein, in seinen Märchen das Bild der Hexe nach eigener Phantasie, gestützt auf übriggebliebene Gerüchte im Volksmund aus der Zeit der Hexenverfolgungen, frei zu kreieren und

15 ebda, 78.

16 ebda, 101 
auszuschmücken, während die Brüder Grimm inre Beschreibungen karger und subtiler nielten.

Daß man durch subtile Veränderungen im Gebrauch der Sprache die Wirkung eines literarischen Stückes ebenso leicht manipulieren kann, bedarf keiner weiteren Erläuterungen. Es ginge auch zu weit an dieser Stelle, eine genaue Untersuchung der Sprache und deren Auswirkung auf die verschiedenen Charaktere im Märchen und besonders auf das Bild der Hexe bei Bechstein und den Brüdern Grimm durchzuführen. Für eine exemplarische ausführliche Untersuchung der Auswirkung der Sprache in den KHM jedoch mochte ich auf Ruth Bottigheimers Artikel "Tale Spinners: Submerged voices in Grimms' 'Fairy Tales' "verweisen. 


\section{DIE INTENTIONEN DER MARCHENERZÄHLER}

Als die Märchen der Brüder Grimm 1810 und 1812 zum ersten Mal veröffentlicht wurden, waren sie nicht sofort erfolgreich. 17 Aber sobald die Brüder einige veränderungen in den Erzählungen vorgenommen hatten, um den Geschmack des Publikums besser miteinzubeziehen, wurden die Märchen zum akzeptierten Lesematerial. Obwohl anfangs eher für Erwachsene als für Kinder gedacht, waren die Grimmschen Kinder- und Hausmärchen bis 1870 "in das Unterrichtscurriculum in Preussen und in anderen deutschen Fürstentümern eingebaut, und sle waren Bestandtell von Fibein und Anthologien fur kinder in der ganzen westlichen Welt,"18 Mittlerwelle bliden die Marchen den Hauptbestandtell des Lesematerlals elnes jeden Kindes. Und für viele Kinder stellen sle das erste Stück Literatur dar, mit dem ein Kind in Berührung kommt. So fragt Frledrich von der Leyen:

Ist es eigentlich in unser Bewußtse in gedrungen, daß unsere Kinder als eines der frühesten Bücher die Kinder-und Hausmärchen kennenlernen und damit ein Meisterwerk der deutschen Prosa?19 In diesem frühen Stadium des Lebens eines Kindes, wenn Ideen gerade erst geformt werden, können der Inhalt und die Charaktere eines solchen

17 Zur Rezeption der Märchen siehe Rolf-Rúdiger Schneidar.

18 "had become incorporated into the teaching curriculum in Prussia and other German principalitles, and they were also included in primers and anthologies for children throughout the western wor ld." Ihe Complete Fairy I gles of the Brothers Grimm, ed. Jack Zipes, prefoce (New York: Bantam Books, 1987) xxix.

19 Von der Leyen, 13 
Lesematerials einen großen Einfluß auf die Entwicklung eines Kindes ausüben. Es ist deshalb erstaunlich, daß es so lange gedauert hat, bis Erzieher, Autoren und Eltern begonnen haben zu untersuchen, welche Wirkung Märchen auf Kinder haben können, speziell in Bezug auf Geschlechts-, Rassen-, und Klassenunterschlede. Obwohl sich Wissenschaftler schon seit langem mit den Märchen selbst befassen, besteht erst seit kurzem die Tendenz, die Märchen unter neuen geschlechts- und klassenspezif ischen Aspekten auf zuarbeiten und deren Auswirkung auf die Sozialisierung von Kindern zu untersuchen. Einige dieser Wissenschaftler kamen mittlerwelle zu der Annahme, daß die Märchen in ihrer Rollenvertellung einseitig und dazu angetan sind, fixierte Rollenverhalten und -funktionen innerhalb einer bürgerlichen Gesellschaft zu fördern.

What became apparent to these writers and critics was that the Grimms' tales, though ingenious and perhaps socially relevant in their own times, contained sexist and racist attitudes and served a socialization process which placed great emphasis on passivity, industry, and self-sacrifice for girls and on activity, competition, and accumulation for boys. 20

Die Märchen der Brüder Grimm und Bechsteins bieten einseitige Modelle für das Benehmen von Jungen und Mädchen, in dem die bösen Gestalten fast alle Frauen in Form von Hexen, Stiefmüttern und Feen sind, während es nur sehr wenige böse Männer gibt, und wenn, sie hauptsächlich in Gestalt von Riesen, Menschenfressern und Räubern auf treten. Des weiteren werden, wie ich später noch ausführlicher erläutern werde, die bösen Frauengestalten am Ende alle mit dem Tode bestraft, während die bösen Männergestalten frei ausgehen. Diese einseitige Erzählweise war Teil einer historischen 
Entwicklung, in dessen Zuge die Brüder Grimm und Bechstein ihre Märchen niederschrieben, teils um zu unterhalten und teils um Moralkodexe für Kinder festzulegen. Und Tell dieser pädagogischen Absicht war es, die gängigen Verhaltensweisen für Jungen und Mädchen zu unterstützen, d.h., die Jungen zu aktivem verhalten zu ermuntern und die Mädchen im Hause zu halten. So wurde Z.B. das Spinnen in den Märchen als oberste Tugend für Mädchen gepriesen, während für faule Mädchen ein garstiges Schicksal ausgemalt wurde. ${ }^{21}$ Und aktive Frauen wurden am Ende für inr Verhalten bestraft, während passive Mädchen zur Belohnung mit etnem Prinzen verheiratet wurden. In diesem Zuge der pädagogischen Belehrung taten die Brüder Grimm und Bechstein inr Tell, die Märchenhexe zu der Schreckgestalt zu machen, als die man sie heute kennt: die böse Alte mit krummem Buckel, roten Augen und Hakennase, wobei Bechsteins Anspruch als Märchenerzähler literarischer war, und wir inm somit ein viel detaillterteres Bild der Hexe verdanken.

Es ist an dieser Stelle notwendig, die Absichten zu untersuchen, die Bechstein und die Brüder Grimm selbst beim Niederschreiben ihrer Märchen hat ten, und sodann verschiedene Kritiker zu Gehör kommen zu lassen, die sich mit den geschlechtsspezifischen Rollen in Märchen und deren Einfluß auf Kinder befaßt haben.

Im Prozess seines Märchensammelns sah Bechstein sich hauptsächlich als Schriftsteller und Künstler, der Geschichten erzählt, um sein Publikum zu amüsieren und zu unterhalten. Er bemünte sich nicht sonderlich,

21 für eine ausführliche Beschreibung der Wichtigkeit des Spinnens in Märchen und den Veränder ungen, die in Märchen in Bezug auf das Spinnen vorgenommen wurden, slehe Ruth Bottigheimers Kapitel "Spinning and Discontent" in ihrem Buch Grimm's Bad Girls and Bold Boys 
Geschichten direkt vom Volk zu bekommen, wie es die Brüder Grimm taten, sondern entnanm die meisten seiner Erzählungen anderen Quellen. Bis er sein Deutsches Märchenbuch (DMB) 1845 veröffentlichte, konnte er "höchstens sechsundzwanzig im DMB erstmals veröffentlichte Erzählungen nach eigenen Aufzeichnungen gewonnen haben"22 weil Bechste in bis 1844, als sein Verleger Georg Wigand inn zum Sammein der Geschichten aufforderte, nur an Sagen gearbeitet hatte. Er hatte keine Märchensammlung vorrätig, und doch sammelte und bearbeitete er alle Märchen des DMB innerhalb von drei Monaten und ließ sie im darauffolgenden Jahr veröffentlichen.

An dieser Stelle ergibt sich das Resümee, daß die vorstellung vom Märchensammler, der seine Erzählungen dem Volksmund abgelauscht hat, in den Bereich der Fiktion zu verweisen ist. ${ }^{23}$

Bechstein hatte somit nie die gleichen Ambitionen mit seinen Märchen wie die Brüder Grimm. Zwar hatte auch er ein "ethisch-didaktisches Anliegen" (Schneider, 5. 79), aber seine "ausgesprochene Neigung zu humorvollem Erzählen" (Schneider, S. 79) war sehr viel ausgeprägter.

Diese Tendenz ist gelegentlich so stark, daß der Humorist den Moralisten korrumpiert, die eigene - ursprünglich ethisch-didaktische

- Wirkabsicht unterläuft, sie ironisch auflöst oder zumindest mit witzlg wirkenden Bemerkungen in der Schwebe hält. ${ }^{24}$ Im Gegensatz zu Bechstein hatten die Brüder Grimm ein moralisch viel tieferes Anliegen für das Sammeln und Erzählen ihrer Märchen. Sie wollten

22 schneider, 41.

23 ebda, 42.

24 ebda, 9. 
nicht so sehr unterhalten, als vielmehr eine nationale volksdichtung erhalten.

Tales, songs, and beliefs of German peasants were, for the Grimms, splintered remnants of the mythology of pagan ancestors suppressed by the medieval church. Their aim was to reconstruct this mythology by piecing together the splinters for the education of the people. According to the brothers, language, religion, and poetry, as well as heroic virtues manifested in the ancestral epic, would make the Germans conscious of their national values and effective in the struggle for national survival and independence in their age of political turbulence The gathering of tale materials, according to Jacob, would lead to a history of German poetry. 25

Obwohl nur eine gute Geschichte zu erzählen, wie Bechstein es tat, innen kein genügender Grund für ihre Märchensammlung war, da sie einen viel größeren Anspruch mit inren Erzählungen hegten, schrieben die Brüder Grimm natürlich auch für Kinder. Zwar erklärten sie nie direkt, daß sie in inren Märchen Rollmodelle für Kinder festlegen wollten, aber daß sie, bewußt oder unbewußt, genau das taten, ist of fensichtlich.

Almost all critics who have studied the emergence of the literary fairy tale in Europe agree that educated writers purposely appropriated the oral folk tale and converted it into a type of literary discourse about mores, values, and manners so that children would become civilized according to the social code of that time. ${ }^{26}$ In diesem Sinne machten sle zwischen den 1810 und 1812 Ausgaben und der endgültigen Ausgabe von 1857 entscheldende Textveränderungen, wobel sie teilweise auch dem Geschmack inres Publikums folgten, da inre

25 Linda Degh, "Grimm's Household Tales and Its Place in the Household: The Social Relevance of a Controversial Classic," Eairy Tales as Ways of Knowing, ed. Michael M. Metzger and Kathar ina Mommsen (Bern: Peter Lang Publishers Ltd. 1981) 23.

26 zipes, 3 
ursprüngliche Sammlung nicht halb so erfolgreich war wie die Bechsteins Leser fanden inre Sprache zu "karg und schmucklos" (Schneider, S.120) im Gegensatz zu Bechsteins Humor und Moral, obwohl auch dessen Stil nicht ganz unbeeinflußt von den Wünschen des Publikums blieb.

Die Purifizierung des DMB, die drastisch-realistische, derb-anstößige oder erotische Stellen betrifft und zur Eliminierung ganzer Texte oder einzelner Zellen führt, resultiert ebenso wie die religiös-erbauliche Komponente (hier galt es aufzufüllen, was auf der anderen Seite zu streichen war) nicht aus einem genuinen Interesse Bechsteins, sondern ist eine gezielte Anpassung an den von Wiegand inaugurierten Käufer-bzw. Leserkreis gewesen.27

Ebenso mußten sich die Brüder Grimm an ihre Leserschaft anpassen, wollten sie erfolgreich sein.

Auch Wilhelm Grimm mußte schließiich Rücksicht auf die Käufer und Leser nehmen, die Sammlung poetisch abrunden, Anstößiges streichen, und es bedurf te verlegerischer weitsicht und Initiative, um den KHM zu ihrem durchschlagenden Erfolg zu verhelfen. 28

Die Brüder Grimm änderten ihre Erzählungen nicht etwa willkürlich, sondern schmückten hauptsächlich dort aus, wo ein moralischer Anspruch zu verteidigen war oder wo eine bestimmte Verhaltensweise als Mahnung oder Vorbild eingeprägt werden sollte. Aus diesem Grunde beziehen sich auch die meisten Textveränderungen auf Stellen, die mit der Rolle der Frau, bzw.

Mädchen, innerhalb des Märchens zu tun haben und die dazu angetan sind, dem Mädchen, bzw. der Frau, ihre korrekte Stellung innerhalb der Gesellschaft zuzuweisen.

27 Schneider, $114 \mathrm{ff}$.

28 ebda, 120 . 
Um nier nur einige Beisplele anzufunren 29 sel die Geschichte König Drosselbarts erwännt, in der König Drosselbart, verkleidet als Bettelmann, die hochmütige Tochter eines Königs heiratet, und in der Folge sie von ihrem Hochmut kurlert. In der Ölenberger Handschrift wird nur erwähnt, daß sich König Drosselbart am Ende als solcher zu erkennen gibt und "sie um Verzeihung [bittet], daß er so hart mit inr umgegangen wäre, zur strafe, daß sie ehemals über inn gespottet hätte"30. In der Fassung von 1812 erniedrigt der König seine Frau auf alle erdenkliche Weise, bis er sie zum Gelächter und Spott des gesamten Königshofs macht, und erst als sie "so beschämt [war], daß sie sich lieber tausend Klafter unter die Erde gewünscht hätte" 31 gibt Drosselbart sich inr zu erkennen, jedoch nicht ohne den neu hinzugefügten moralischen Anspruch, "das alles ist nur dir zur Besserung und zur Strafe geschehen, well du mich ehedem verspottet hast"32. Dieser Anspruch, daß alles nur zum besten der Prinzessin geschah, wird in der endgültigen Fassung von 1857 noch unterstrichen, indem hier die Prinzessin am Ende ihr vorgehen (das in der Verspottung des König Drosselbarts zu Beginn des Märchens lag) bereut.

Da weinte sie bitterlich und sagte: «Ich habe großes Unrecht gehabt und bin nicht wert, deine Frau zu sein. $\$ 33$

29 für ausführliche Textvergleiche siehe John Ellis' One Fairy Tale Too Many, Ruth Bottigheimer's Grimm's Bad Girls and Bold Guvs und Heinz Rölleke's Wo das Wünschen noch geholfen hat (Bonn: Bouvier Verlag Herber Grundmann, 1984).

30 Rölleke, 118.

31 ebda, 121.

32 ebda, 121.

33 KHM, Band I, 268. 
Dieses Märchen erinnert deutlich an Shakespeares Taming of the Shrew, indem beide Male die ursprüngliche übermütige Vernaltenswelse des Mädchens verurteilt und durch die Machenschaf ten eines Mannes bestraft wird, um sie am Ende folgsam und gefügig zurück in den Schoß der Familie und Ehe zu führen. Die Brüder Grimm veränderten das Ende von König Drosselbart nach einer Neuerzählung von Dortchen Wild, aber auch ganz offensichtlich im Hinblick auf eine Betonung des anfänglichen

Fehiverhaltens und auf ein Unterstreichen der Bewußtseinsveränderung, die in dem Mädchen vorgegangen ist.

Ein Beisplel für das Spinnen als eine Aufgabe, die zwar hart ist, aber am Ende belohnt wird, wenn das Mädchen nur fleißig und folgsam genug ist, ist das Märchen vom Rumpelstilzchen In einer früheren version ist die Heldin ein Mädchen, das alles Stroh, das inr zum Spinnen gegeben wird, automatisch in Gold verwandelt und darüber sehr traurig ist. Zwischen der 1810 und 1812 Version verandert Wilhelm Grimm dieses Motiv. in sein genaues Gegenteil.

The motivation for the entire tale shifts from the girl's being released from spinning gold (1810) to her being forced to spin gold at the risk of her life $(1812)^{34}$.

Aus dem selbständigen Mädchen mit einer natürlichen Gabe wird ein hilfloses Geschöpf, das von ihrem Vater zum König geschickt wird, um dessen Gler nach Gold zu befriedigen. Die Junge Frau muß sterben, es sei denn, inr wird von einem anderen Wesen geholfen.

In der Entwicklung der Geschichte Dornröschensvon der Ölenberger Handschrift zu der sechsten Ausgabe kann man eine ähnliche Veränderung 
beobachten In dem handgeschriebenen Manuskript von 1810 ist das Madchen einfach eine "Tochter" onne weitere Eigenschaften. In der ersten veröffentlichten version von 1812 wird sie als ein "Wunder von Schönheit" beschrieben, und von der zweiten Ausgabe an ist sie ein Bündel an Tugend und Schönheit ("es war so schön, sittsam, freundlich und verständig, daß es jedermann, der es ansah, lieb haben mußte"). Mit dem Wachstum inrer Tugenden wächst auch inre Abnängigkeit von dem Prinzen.

Ebenso wie das Bild Dornröschens ändert sich das Bild der bösen Fee zwischen der handschriftlichen version von 1810 und den Ausgaben von 1812 und 1850. In der Handschrift und den ersten zwei Ausgaben werden alle Feen gleich behandelt. Sie werden entweder als "Feen" oder als "weise Frauen" erwähnt, aber es gibt keinen Unterschied in der Benennung der dreizehnten Fee, die man einzuladen vergessen hat, und den anderen. Die Art und Weise jedoch, in der der Wunsch ausgesprochen wird, llefert Anhaltspunkte für die spätere Veränderung des Charakters der Fee. In der handschriftlichen Version "verkündet" die dreizehnte Fee, daß die Königstochter sich an ihrem fünfzennten Geburtstag an einer Spindel stechen werde und sterben solle. In der ersten Ausgabe von 1812 betritt die Fee den Saal "recht zornig, daß sie nicht war eingeladen und rief ..."35. In der zwelten Ausgabe von 1814 sinnt die Fee auf Rache und inr böser Wunsch wird zu einer "Verwünschung". In dieser Ausgabe wird sie auch zum ersten Mal nicht mehr Fee sondern "Zauberweib" genannt. Schließlich wird in der sechsten Ausgabe von 1850 die Verbindung zwischen Hexerel und der dreizehnten Fee deutlich gezeichnet. Inr Wunsch wird zu einem

35 für eine ausführlichere Analyse der Unterschiede zwischen "sprechen", "sagen" und "rufen" siehe Ruth Bottigheimer, Grimm's Bod Girls and Bold Guys. 
"Zauberspruch" und inr Einzug auf das Geburtagsfest der Prinzessin wird zu einem dramat ischen Ereignis":

Sie wollte sich dafür rächen, daß sie nicht eingeladen war, und ohne jemand zu grüßen oder nur anzusehen rief sie mit lauter Stimme ... Und ohne ein Wort weiter zu sprechen kehrte sie sich um und verließ den Saal. Alle waren erschrocken ... .

Wie schon erwähnt, beziehen sich die Textveränderungen hauptsächlich auf die Rollen von Mädchen, bzw. Frauen. Es erscheint mir deshalb als wahrscheinlich, daß die Märchen einen anderen Einfluß auf Leserinnen als auf Leser haben, und daß Mădchen andere, einseitigere Rollenvorbilder in den Märchen vorf inden als Jungen. Diese einseitigen Veränderungen scheinen mir auch mit daran Schuld zu sein, daß das Bild der Hexe so vorwiegend negativ gezeichnet erscheint. 


\section{GESCHLECHTSSPEZIFISCHE ROLLENUNTERSCHIEDE}

Ob aleser Hang zu geschlechtsspezlfischen Rollen in Marchen tatsachlich existiert, ist schon seit langem Mittelpunkt einer Diskussion zwischen Psychologen, Historikern, Erzlehern, Folkioristen, Germanisten und vielen anderen. Bruno Bettelheim, selbst ein führender Kinderpsychologe, behauptet, daß das Genus eines Charakters in einem Märchen für die Auswirkung auf das kind nicht ausschlaggebend sel.

Recently it has been claimed that the struggle against childhood dependency and for becoming oneself in fairy tales is frequently described differently for the girl than for the boy, and that this is the result of sexual stereotyping. Fairy tales do not render such one-sided pictures. Even when a girl is depicted as turning inward in her struggle to become herself, and a boy as aggressively dealing with the external world, these two together symbolize the two ways in which one has to gain selfhood: through learning to understand and master the inner as well as the outer world. In this sense the male and female heroes are again projections onto two different figures of two (artificially) separated aspects of one and the same process which everybody has to undergo in growing up. While some literal-minded parents do not realize it, children know that, whatever the sex of the hero, the story pertains to their own problems 36.

N.J.Girardot ist wie Bettelneim der Ansicht, daß geschlechtliche Unterschlede weniger wichtig seien als die psychologische Signifikanz der Märchen37. Diese Auffassung läßt Jedoch völlig außer Acht, daß es in den

36 Bruno Bettelheim, Ihe Uses of Enchantment (New York: Vintage Books, 1977) 226.

37 "gender differences are less impartant than the psychological significance of the tales." N.J.Girardot, "Initiation and Meaning in the Tale of Snow White and the Seven Dwarfs," Jeurnal of American Foklore 90 (1977): 284. 
Märchen 37. Diese Auffassung laßt jedoch völlig außer Acht, daß es in den meisten Märchen tatsächlich die Jungen sind, die hinaus in die Welt zienen, und Abenteuer erleben, während die Mädchen zu Hause bleiben und auf inren Prinz warten. Obwohl das wohl durchaus den Gepflogenheiten des Grimmschen und Bechsteinschen Jahrhunderts entsprach, wird es an der Zeit, diese Rollenverteilung aus historischer Perspektive kritisch zu untersuchen und auf ihren Gehalt für moderne Leser zu überprüfen.

Eine andere Gruppe von Wissenschaftlern, unter innen Alison Lurie, Stith Thompson und Max Lüthi, halten das Geschlecht der Märchencharaktere für wichtig, finden jedoch, daß Märchen positive Vorbilder sowohl für Jungen als auch für Mädchen bieten. So meint A. Lurie zum Beispiel:

These stories suggest a society in which women are as competent and active as men, at every age and in every class... The contrast is greatest in maturity, where women are of ten more powerful than men. Real help for the hero or heroine comes most frequently from a fairy godmother or wise woman; and real trouble from a witch or wicked stepmother. 38

Wiederum beschäftigt sich diese Ansicht nicht mit dem häufigeren Vorkommen von bösen weiblichen Gestalten im Vergleich zu bösen männlichen Gestalten, und sie verleint überdies der Überzahl an bösen Hexen im Gegensatz zu den relativ geringen und kurzen Auftritten der weisen Frauen kein Gewicht , Ich stimme daher Kay F. Stone $z U$, wenn sie sagt:

Lurle, Lüthi, and Thompson all emphasize that fairy tales demonstrate the power of women simply because these stories are dominated by

37 "gender differences are less important than the psychological significance of the tales." N.J.Girardot, "Initiation and Meaning in the Tale of Snow White and the Seven Dwarfs," Journal of American Foklore 90 (1977): 284.

38 Alison Lurie, "Fairy Tale Liberation," New York Review of Books (Dec. 17, 1972): 42 
women, both as protagonists and as narrators. None of them mentions that most of the heroines are pretty and passive rather than powerful.39

Um geschlechtsspezif ische Rollenunterschiede in Märchen zu untersuchen, darf man nicht nur die vorkommende Anzahl von Frauen zählen, sondern man muß die Art der Rollen kritisch betrachten und sich fragen, wie diese das Selbstgefühl eines Mädchens bestimmen können.

Millions of women must surely have formed their psycho-sexual selfconcepts, and their ideas of what they would or could not accomplish, what sort of behavior would be rewarded, and of the nature of the reward itself, in part from their favorite fairy tales. These stories have been made the repositories of the dreams, hopes and fantasies of generations of gir 15.40

Diese Art von geschlechtsspezif ischer Rollenuntersuchung ist noch relativ neu und wurde hauptsächlich von Mitgliedern der feministischen Bewegung entwickelt. Frauen wie Simone de Beauvoir, Marcia Lieberman und Rosemary Minard finden, daß entscheidende Unterschiede zwischen Helden und Heldinnen existieren, und daß diese wichtig sind, da sie zu verschiedenen Sozialisierungsprozessen für Jungen und Mädchen in der modernen westlichen Gesellschaft beitragen ${ }^{41}$. Die Brüder Grimm selbst trugen zu diesem Sozialisierungsprozess durch die Art und Weise, wie sie inre Texte veränderten, entscheidend bei.

39 Kay F. Stane, "The Misuses of Enchantment: Controversies on the Significance of Fairy Tales," Women's Folklore. Women's Culture, ed. Rosan A. Jordan, Susan J. Kalcik (Philadelphia: University of Pennsylvania Press, 1985) 127.

40 Marcia Liebermann, " 'Some Day My Prince Will Come': Female Acculturation Through the Fairy Tales," Colleae Enolish 34 (1972): 385.

41 "significant differences in heroes and heroines exist and these are important because they contr ibute to different sacialization of boys and girls in contemporary western society," Stone, 130. 
Wilhelm Grimm himself knew that the tradition he was editing differed even from that of Germany's nearest neighbors to the north, for he had published Altdänische Heldenlieder, Balladen und Märchen in 1811, a year before Grimm's Talesfirst appeared in print. Many of the heroines in the Danish ballads and tales demonstrate an independence utterly alien to the women in later editions of the Talest2

In den Märchen der Brüder Grimm und Bechsteins erscheinen Frauen als unabhängig und stark fast nur in der Rolle der alten Frau. Besonders was die Rolle der Hexe anbelangt, muß man sich fragen, warum sie so einseitig negativ porträtiert wird. Woher kommt dieses Bild der bösen Hexe? Wurde die alte Frau schon immer als böse angesehen? Im nächsten Kapitel werde ich diese Fragen unter besonderer Berücksichtigung der etymologischen Entwicklung des Wortes 'Hexe' und der Entwicklung der christlichen Kirche und deren Einfluß auf die 'Hexe' als Stereotyp untersuchen. 


\section{KAPITEL $\|$ \\ DIE HEXE IN DER GESCHICHTE}

\section{ETYMOLOGISCHE UNTERSUCHUNG DES WORTES 'HEXE'}

Wenn man versucht, den Begriff der Hexe etymologisch-historisch zu erschließen, so ist es von äußerster Wichtigkeit, dem Ursprung des Wortes 'Hexe' unter Berücksichtigung der geschichtlichen Entwicklung vor und nach dern Mittelalter nachzugehen, da diese Epoche einen entscheidenden Abschnitt in der Geschichtsauffassung darstellt. Dies wurde meiner Meinung nach bisher von dem meisten Historikern vernachlässigt und hatte ein dementsprechend verzerrtes Bild des Begriffes 'Hexe' zur Folge. Ich werde deshalb zunächst versuchen, den Ursprung des Wortes 'Hexe' so weit möglich zu erläutern und sodann eine Trennung des Begriffes zwischen vor-und nachmittelalterlicher Auffassung vornehmen.

Der Ursprung des Wortes 'Hexe' ist keinesfalls eindeutig und daher of fen für mancherlei Spekulationen. So findet man in fast jedem etymologischen Wörterbuch eine andere Erklärung für die ursprüngliche Bedeutung des Wortes. Ich möchte hier nur einige weitverbreitete Spekulationen anführen, und sodann meine eigene Schlußfolgerung zienen.

Worüber sich die meisten Forscher einig sind, ist, daß sich das Wort 'Hexe' auf das altgermanische beschränkt und auf das Wort hagazussa ein Kompositum bestehend aus dem Bestimmungswort hag und einem Grundwort zussa, zurückzuführen ist. Was nun die Interpretation von hag und zussa 
betrifft, so gibt es verschiedene Meinungen. In den meisten Wörterbüchern wird hag mit Zaun, Hecke, Gesträuch übersetzt, während das wort zussa verschiedene Interpretationen erfährt. Die gebräuchlichste Übersetzung des Kompositums scheint sich jedoch in der 'Zaunreiterin' wiederzuf inden.

Das Bestimmungswort ist wahrsche inlich das unter Hag "Zaun, Hecke, Gehege" dargestellte Substantiv, das Grundwort, das bis heute nicht sicher gedeutet ist, gehört vielleicht mit norwegisch tysja "Elfe" zusammen. Demnach wäre Hexe ein sich auf Zäunen oder Hecken aufhaltendes dämonisches Wesen, beachte aisl. tunrida "Hexe" elgentitch "Zaunreiterin". Im ausgehenden Mittelalter ging das Wort für einen - dem Volksglauben nach - [bösen] wetblichen Geist auf eine Frau über, die mit dem Teufel im Bunde stent und über magischschädigende Kräfte verfügt,...1

Trübners Deutsches Wörterbuch gibt eine andere Grunddeutung des Wortes hagazussavon Lauffer. Er kommt aber zu dem selben Resultat.

Am wahrscheinlichsten Ist wohl die Deutung aus ags. teona teone 'Schaden, Verderben', tienan 'schädigen', die zu einer indogermanischen wurzel dau-gehoren. Dann wäre die Hexe der welbliche Dämon, der von der Einfriedung des Gehöftes aus Verderben stif tet. 2

In demselben Eintrag wird später über Lauffers Vermutung berichtet:

Er kommt zu dem begründeten Ergebnis, daß die Hexe als eine Unholdin anzusehen sei, die auf den das menschliche Besitztum umhegenden Zäunen sitzt, über dle sie nicht hinwegkommen kann. So lauert sle auf Mensch oder Tier, die sich ihr leichtfertig aussetzten. Die Bezeichnung des Zaunes als hag weist auf seine Herkunft von Baum

1 Der aroße Duden. Etymologie. Herkunftswörterbuch der deutschen Sorache, Band 7, bear D. von der Dudenreaktion unter Leitung von Paul Grebe (Mannheim: Bibliographisches Institut, 1963) 264.

2 Lauffer, Irübners Deutsches Wörterbuch. Hsg. Alfred Göße, Dritter Band (Berlin: Walter de Gruyter \& Co, 1939). 
und Hecke, und die zahlreichen Belege fur das Vorkommen boser bisweilen aber auch guter - Geister in Baum und Strauch bestärken noch Lauffers Zauntheorie. Zur Zaunhexe stimmt auch gut das Hexentier, die Katze, die ja ebenfalls den Platz auf dem Zaune bevorzugt, und in deren Gestalt die Hexe mit Vorliebe auf taucht. Daß alles in allem ein Zusammenhang besteht zwischen Wald, Hecke und Zaun, dürfte nicht zu leugnen sein. ${ }^{3}$

Dieser letzte Satz wird für meine eigene Interpretation noch von großßerer Bedeutung sein. Zunächst jedoch möchte ich noch einige weitere Interpretationen zitieren. Friedrich Kluge führt das Wort 'Hexe' auf das and Wort 'zunrita' und das anord. tunrida= Zaunreiterin, Hexe zurück

Dem Grundwort germ. tusjo(auch in westfäl. dus 'Teufel', norw. tysja 'Elfe'; verkrüppeites Weib) vergleicht sich gall. dusius 'unreiner Geist', korn. Dus, Diz 'Teufel', alt lit. dvasa, heute dvasia 'Geist': Wurzel dhus-: dhuos. 4

Die meisten Forscher sahen die Hexe also als ein dämonisches Wesen, zwar ursprünglich nicht unbedingt weiblich, das sein Unwesen in dem Bereich zwischen Zivilisation und Wildnis trieb.

As late as the Middle Ages, the witch was still the hagazussa, a being that sat on the Hag, the fence, which passed behind the gardens and separated the village from the wilderness. She was a being who participated in both worids. As we might say today, she was semidemonic 5

Interessanterweise hat das englische Wort 'witch' einen anderen Ursprung als das deutsche Wort 'Hexe'. 'Witch' geht zurück auf das anglo-sächsische wic'to bend or shape' zurück und ist verwand mit wite, wis-, wita, wicta,

3 Ruth Westermann, Irübners Deutsches Wör terbuch.

4 Friedrich Kluge, Etymologisches Wörterbuch, (Ber lin: Walter de Gruyter \& Co., 1967).

5 Hans Peter Duerr, Dreamtime: Concerning the Boundary Between Wilderness and Civilization, trans. Felicitas Goodman (New York: Basil Blackwell, Inc. , 1985) 46. 
witan was oft mit 'wise' übersetzt wird. ${ }^{6}$ Demnach ist die englische Hexe in inrem Ursprung eine weise Frau (wise woman) und hat wenig mit Dämonen oder Untaten zu tun. Die Brüder Grimm scheinen diese Auffassung zu teilen, indem sie den Ursprung des Wortes 'Hexe' als "verschmitztes Welo" [= wise woman?] angeben.

Grimm zieht zur Erklärung altn. hagr klug heran, so dasz hexe den Sinn verschmitztes Weib hatte; andere deuten sie mit bezug auf hag als waldweib?

Daß es eine Verbindung zwischen der weisen Frau und dem Waldweib gibt, findet auch in anderen Bezeichnungen, die man für die Hexe findet, eine Resonanz. So wird sle oft auch als Herbaria, "Kräuterfrau", "Holzfrau", u.ä. tituliert.

Bei der Bezeichnung Herbaria "Kräuterfrau" denkt man an die ae. "angenga die einsam Herumschweifende". Durch diese lbe Glosse ergibt sich eine Berührung mit lamia die gewöhnlich mit holzmuoia (Holzmütterchen) glossiert wird. Identisch sind Holzweib und wildes Weib. Der Übergang und die Vermischung von der einsamen Kräutersammierin zur Waldfrau im Volksglauben ist einleuchtend. Die verschledenen Wald-und Alpgeister, die nach den Überlieferungen in naher Beziehung zu der Hexenvorstellung stehen, haben z.T. eine erotische Natur, was auch zu den Begriffen striga-meretrix-hazzusganeo-histrio paßt, allen gemeinsam ist das "Umherschwelfen". Nach alledem ist es kaum möglich, die verschledenen Vorstellungen des Volksglaubens (Alp-, Wald-und Totengeister), die sich an den Namen und Begriff anschließen, genau voneinander zu scheiden, eine Schwierigkeit, auf die wiederholt, mit besonderer Vorsicht, von Franck hingewiesen wurde. 8

6 Barbara Walker, Ihe Woman's Encyclopedia of Myths and Mysteries, (San Francisco: Harper \& Row, 1983) $1076 \mathrm{ff}$.

7 Matthias Lexer, Mittelhochdeutsches Handwörterbuch (Stuttgart: S. Hirzel Verlag, 1974).

8 Handwörterbuch des Deutschen Aber glaubens, Hrsg. Hanns Bächtold-Stäubli, (Berlin und Leipzig: Walter de Gruyter \& Co., 1930/1931) 1828 ff. 
Im Sinne der oben angeführten verschiedenen Interpretationen möchte ich nun meine elgenen Nachforschungen und Spekulationen anschließen. Wenn man das Wort 'hag' weiter verfolgt, stößt man interessanterweise nicht nur auf die Bezeichungen 'Zaun, Hecke', sondern auch auf Begriffe wie ahd. 'Einhegung' und mhd. hac 'Dorngesträuch, Gebüsch; Umzäunung, Gehege; [umfriedeter] Wald; lumfriedeter] ort', weiterhin schwed. hage 'Gehege; Weide; Wäldchen; Hain' 9 Dieser Hain oder umfriedete Wald jedoch war in vorchristlichen Zeiten der Hauptort, an dem religiöse Feiern und Gottesdienste abgehalten wurden.

From an examination of the Teutonic words for "temple" Grimm has made it probable that amongst the Germans the oldest sanctuaries were natural woods. However this may be, tree-worship is well attested for all the great European families of the Aryan stock. Amongst the Celts the oak-worship of the Druids is familiar to every one. Sacred groves were common among the ancient Germans, and tree-worship is hardly extinct amongst their descendants at the present day. 10

Da es in vorchristlichen Zeiten hauptsächlich Frauen waren, die als Priesterinnen fungierten"l möchte ich die Hypothese aufstellen, daß das and. Wort 'hagazussa' ein Überbleibsel ist aus einer Zeit, in der heidnische Völker einer Art von Naturverehrung unter der Leitung von Priesterinnen anhingen. Ich meine, daß der Begriff daher im Zusammenhang mit dem englischen 'wise woman' steht, da er sich ebenso wie 'witch' auf frührere

\section{${ }^{9}$ Der aroße Duden.}

10 Sir James Frazer, Ihe New Golden Bough (New York: S.G.Phillips, Inc., 1959) 107.

11 siehe Merlin Stone, When God Was a Woman (New York: Harcourt Brace Jovanovich, 1973) und Starhowk, Iruth or Dare (San Francisco: Harper \& Row, 1987). 
weise Frauen, Heilerinnen und Priesterinnen bezieht, und sich erst im Laufe des Christianisierungsprozesses zum Begriff der bösen Hexe, wie er heute allgemein gebräuchlich ist, wandelte

Um diese Hypothese zu untermauern ist es notwendig, zu erforschen, wie das deutsche Wort Hexe, abgeleitet von 'hagazussa; zum ersten Mal verwendet wird. Der Begriff der Hexe als ein Zauberwesen wird verschiedentlich schon in früheren Schriften erwähnt, man muß jedoch unterscheiden, ob man von dem vorchristlichen Bild der Zauberin spricht, wie sie bei Horaz, Ovid, Apuleius, Seneca und Theocritus, um nur einige zu nennen, erscheint, oder ob man das Bild der Hexe, wie es im Mittelalter und danach porträtiert wird, meint. Meiner Meinung nach machten die meisten Forscher den Fehler, daß sie die vorchristliche Hexe, die ursprünglich mit ganz anderen Namen bezeichnet wurde (siehe striga, lamia, ruria) und die ich von nun an mit dem Wort 'Zauber in' im Gegensatz zu 'Hexe' benennen möchte, unter dem Aspekt der mittelalterlichen Hexe sahen, onne die dazwischenliegende Entwicklung des Christentums und dessen Auswirkung auf den Volksglauben zu berücksichtigen.

Since nearly all early histories were written by Christians, Christian concepts of a Devil were superimposed on folk beliefs; and late scholars, familiar with the background of a developed demonology, have read into these histories conceptions originally alien to them. 12 Daß es vor dem Mittelalter Zauber Innen gegeben hat, wird verschiedentlich in der Literatur erwähnt. Jedoch entsprechen diese Zauberinnen einem ganz anderen Volksglauben, als die späteren mittelalterlichen Hexen. In dem

12 Rossell Hope Robbins, Ihe Encyclooedia of Witchcraft and Demonologe (New York: Crown Publishers, Inc., 1959) 547. 
Weltbild vieler vorchristlicher Völker nahmen Frauen eine relat iv hohe Stellung ein und waren nicht nur für das geistige, sondern auch für das leibliche Wohl des Volkes zuständig. Sie waren of tmals weise Frauen und Hebammen, kräuterkundig und in der Medizin bewandert.

Bei den Germanen lag die Heilkunde und vor allem die Geburtshilfe in den Händen von kräuterkundigen Frauen, und in den Sagas sind sie wegen inres Wissens berühmt. Sie behande In kranke Männer und Frauen gleichermaßen und machen erste Fortschritte in der Geburtshilfe, indem sie die Geburt durch die Anwendung schmerzlindernder, krampfstillender, wehenfördender Kräuter wie Wacholder, Kamille, Beifuß oder Mutterkorn erleichtern. Daß die Frauen der patriarchalisch organisierten germanischen Stämme in der Heilkunde eine so hervorragende Rolle spielten, entsprach dem im religiösen Kult zum Ausdruck kommenden Naturverständnis der Germanen. Die Frau wurde durch inre Gebärfähigkeit, die unter anderem die Fruchtbarkeit der Natur symbolisierte, in einem engeren Verhältnis zu der von Dämonen beherrschten Natur gesehen. Daher wurden inr auch seherische Gaben und die besondere Kenntnis von zauberkräftigen (=heilenden) Kräutern zugeschrieben.13

In diesem Naturverständnis waren jedoch gut und böse noch nicht getrennt, der Glaube an Dämonen und Zauberwesen hatte eine ganz andere Dimension als im späteren christlichen Weltbild.

In folk medicine, both black and white magic had their place: here both the wise and evil woman had her social function. This polarity did not yet correspond to the moral duality of good and evil, a duality whose function was changed by Christianity. It corresponded to the ambivalence of nature's effect on agrarian life: the good harvest and the destructive drought, the healing herbs and the lethal mushroom. in going back to pagan demonology in order to discredit women, the Church at that time made women responsible for only the evil effects of nature. In reality their intent was to dissolve the bond between

13 Becker, Bovenschen, Brackert u.8. . Aus der Zeit der Verzweifluno - Zur Genese und Aktualität des Hexenbildes (Frankfurt/Mrin: n.8., 1977) 85. 
women and nature and to destroy the aura of feminine magic once and for all. 14

Obwohl auch einige Forscher wie Hans Biedermann behaupten: "Der Hexenglauben ist keineswegs eine Erfindung jener Zeit, in der die meisten Hexenprozesse stattfanden, sondern war schon in der Antike bekannt," 15 beruft Biedermann sich hier ausschließlich auf Quellen (fast alle römische), in denen Hexen nicht unter dem Namen Hexe, sondern unter anderen Namen wie sagae, striges, venficiae, lamiae erwähnt werden und fährt dann selbst fort:

Hier ist freilich nicht immer genau entscheidbar, ob es sich um den Ausdruck eines echten Volksglaubens oder bloß um literar. Spielerei handelt. Zu wenig beachtet wird meist, daß der Glaube an Hexen (meist, aber nicht ausschließlich, weiblichen Geschlechts) nicht ein spezifisch europäisches Phänomen, sondern praktisch weltweit verbreitet ist; ... Auch im vor-und frühchristl, Nordeuropa war die Gestalt der Hexe in verschiedenen Varianten (. . .) bekannt und gleichermaßen geachtet und gefürchtet. 16

Wie Biedermann richtig feststellt, war die Gestalt der Hexe schon in vorchristlichen Zeiten bekannt, aber unter anderen Namen und in anderen Rollen: als saga= weise Frau sowohl als auch als furia und striga, als Heilerin sowohl als auch als todbringende Dämonin.

Schließlich wird verschiedentlich versucht, den Hexenglauben auf eine Verteufelung matriarchalischer Kulturphänomene durch betont maskuline Gesellschaften zu erklären; daß also Kulturen mit

14 Silvia Bovenschen, "The Contemporary Witch, the Histor ical Witch and the Witch Myth: The Witch, Subject of the Appropritation of Nature and Object of the Domination of Nature," New German Critique, 15 (Fall 1978): 102.

15 Hans Biedermann, Handlexikon der magischen Künste, Dritte verbesserte und wesentlich vermehrte Aufloge. Band I ( Groz-Austria: Akodem ische Druck- und Ver logsanstalt, 1986) 203.

16 ebda, 205. 
Herrscherinnen und Priesterinnen durch eine männliche Revolution entmachtet und für teuflisch erklärt worden seien. In dieser extremen Form ist diese Annahme gewiß nicht haltbar, doch stent fest, daß die Rolle der Frau im Kultus und als Erbträgerin in vielen alten Kulturen größer war als in unserer hist. Epoche. Relikte von Frauenkulturen etwa in der dörflichen "Kleinmagie" können tatsächlich Anhaltspunkte für Hexenverfolger gewesen sein, die Doktrinen außerkirchlicher Sekten (. . . )mit den zunächst tolerierten Brauchtumsresten vermengten (...) 17

Obwohl es also schwer nachzuweisen ist, daß die Fraven der Antike tatsachlicm bose Zauber inmen waren, kann sehr wohl festgestellt werden, ab wann der Begriff der Hexe ein bösartiges Wesen, und ganz spezifisch eine bösartige Frau darstellt. 18

Das Wort Hexe ist in den literarischen Denkmälern bis zum 14. Jh. selten nachweisbar. Vom 13. Jh. an beginnt es auf schweizerischem (alemannischem) Sprachgebiet Hexe im Sinne der Hexenprozesse zu bedeuten. In dieser Bedeutung hat es vom 15. Jh. ab durch die von süddeutschland nach dem Norden vordringende Hexenverfolgung allgemeine verbreitung gefunden. 19

Auch auf dem Gebiet der Kunst tritt die Hexe erst ab dem Ende des 15. Jahrhunderts in Verbindung mit dem Teufel auf. Das erste Portrăt in Lehners Picture Book of Devils. Demons and witchcraft 20 stammt aus dem Jahre

17 ebda, 212.

18 Es ist hier nicht meine Absicht, einen längeren Überblick über die Geschichte der Hexenver folgung zu geben. Das wäre eher das Thema einer weiteren For schungsarbeit und hier fehl am Platz. Gestützt auf verschiedene Abhandlungen, die jede für sich im einzelnen meine Punkte näher und ausführlicher erläutern, werde ich hier nur einen groben Umriß, soweit es meines Erachtens nach für die späteren Märchen von Bedeutung sein wird, zeichnen.

19 Bächthold-Stäubli, 1834.

20 Ernst und Johanna Lehner, Picture Book of Devils. Demons and Witcheraft (New York: Dover Publications, 1971). 
1473 und zeigt den Teufel Belial, während Albrecht Dürer 1497 ein Bild "Die vier Hexen" tituliert. 


\section{DAS ERSCHEINEN DES HEXENBILDES IN DER GESCHICHTE}

Wie schon in den etymologischen Ausführungen gezeigt, tritt der Begriff der Hexe als solcher erst nach dem 13. Jh. auf und reint sich im Zuge der Christianisierung in eine neue christliche Definition ein. Zum ersten Mal wird die Hexe genauer von George Gifford beschrieben 1587 :

A witch is one that worketh by the Devil, or by some devilish curious art, either hurting or healing, revealing things secret or foretelling things to come, which the Devil hath devised to entangle and snare men's souls withal unto damnation. 21

Und William Perkins fährt 1608 fort:

A witch is a magician, who either by open or secret league, wittingly and willingly consenteth to use the aid and assistance of the Devil in the working of wonders. 22

Von nun an erscheint die Hexe per Def inition immer in Verbindung mit dem Teufel. Dies bedeutet eine Veränderung in der Haltung der Kirche gegenüber heidnischen Bräuchen und leitet den Beginn eines neuen Phänomens ein, das Hexen als dämonische Wesen im Bund mit dem Teufel sieht.

Wichtig ...ist auch der sogenannte "Canon episcopi" aus dem 10. Jahrhundert, der die of fizielle Haltung der Kirche zu heidnischen Bräuchen bis ins 11. und 12. Jahrhundert bestimmte. Nach dem "Canon" war der Glaube an Zauberel heldnisch und die Ausübung der Zaubere1 etwas Ketzerisches. ...Die Glaubensvorstellungen der nur äußerlich christianisierten Völker wurden damals von der Kirche so heftig bekämpft, weil sie sich eine Machtstellung neben den teilweise noch

\section{Robbins, 546.}

22 ebda, 546. 
recht heidnischen Franken aufbauen wollte $1 \mathrm{~m} 11$. und 12. Jahrhundert verändert sich dann die Haltung der Kirche zur Zauberei. Die Menschen sollen jetzt gerade an Zauberei und den Teufel glauben. Aus Angst vor dämonischen Kräften sollten sie sich verstärkt dem Glauben an den christliche Gott zuwenden. 23

Ein Teil dieses Machtkampfes 2 wischen Kirche und heidnischem Glauben äußerte sich nun in der Dämonisierung heidnischer Bräuche. Dazu gehöte auch die bewußte Verteufelung alter magischer Praktiken und deren Hauptausübende - der Frauen.

In the Canon episcopl of 900 A.D. (which still vehemently denles the actual existence of demons) the image of Diana appears, the goddess who, according to popular belief, flies through the air followed by a horde of women. Later, during the period of witch persecution, clerics were busy warning people about the threat of a return of matristic power (for example, Aventin and the witch persecutor Boguet).24

Auch das Wort 'Hexerei' erlangt im Mittelalter eine völlig neue Bedeutung, die eng mit der Kirche und dem Glauben an den Teufel liiert ist.

Some time about the middle of the fourteenth century, witchcraft began to acquire a different form; gradually, out of the old concept of magic grew the new concept of heresy. Heresy was treason against God, and may be defined in the words of Bernadus Guidonis (126)1331) as "the knowing rejection of a dogma or the rigid adherence to a sect whose doctrines have been condemned by the church as contrary to the faith." The first reference to the new witchcraft seems to be in the trials at Toulouse and Carcassonne, before 1350, by which time 600 persons had been burned as heretics. 25

23 Hexen. Katalog zur Wanderaustelluno "Hexen" aus dem Hambura. Museum für Välkerkunde, Hrsg. Thomas Hauschild (Berlin: Zerling, 1986) 15.

24 Bovenschen, 100 .

26 RODDInS, 548. 
Mit dem Erscheinen des Hexenhammers in 148726 wurde nun auch das

Erscheinen der Hexe in eine ganz bestimmte Form gepreßt. Während vorher nur ein loser Begriff herrschte, was nun genau als Zauberel galt, wurden jetzt die Aktivitäten der Hexe genauestens festgelegt und reguliert. Nicht nur gab es verschiedene Kategorien von Hexen, es wurden nun auch typische Merkmale wie Hexenritte, Hexensabbath und Hexentinkturen umrissen und genaueste Anweisungen zum Aufspüren einer Hexe gegeben.

Zu den Hauptkennzeichen einer Hexe nach dem "Hexenhammer" gehörten die Abschwörung Gottes und der Pakt mit dem Teufel, der geschlechtliche Umgang mit dem Teufel, also die "Teufelsbuhlschaft" als Bekräftigung dieses Paktes, der Schadenzauber, der Flug durch die Luft und die Verwandlung in Tiere sowie die Teilnahme am Hexensabbat, der Teufelstanzversammlung. ${ }^{27}$

Aber wer genau wurde nun als Hexe angeklagt und wessen wurden sie beschuldigt?

Viele Autoren gehen davon aus, daß es zwar den Glauben an Frauen mit übernatürlichen Kräften im Volk gab, daß aber die eigentlichen Hexen, die verbrannt wurden, nichts weiter als Opfer einer unerbittlichen Maschinerle waren. Opfer auch der Denunziation, der Folter, der Anklagen. Opfer, für die es kein Entrinnen gab: denn es war egal wie sich eine Frau verhielt, brav, aufmüpfig, schlau, dumm, keß, schüchtern...-zur Hexe konnte sie allemal gemacht werden. ${ }^{28}$ Obwohl prinzipiell jeder der Hexerel angeklagt werden konnte, waren es überwiegend Frauen, die als Hexen verurteilt wurden. Als besonderes Ziel

26 Johann Sprenger und Heinr ich Institor is, Malleus Maleficarum. Der Hexenhammer, (1487), transl. J.W.Schmidt (Berlin, 1906, Rpt. Dermstadt, 1974).

27 Waltraut Jilg. "Der Begriff "Hexe" und seine Komplexität," Ieufelsolaube und Hexenprozesse, Hrsg. Georg Schwaiger (München: Beck, 1987) 42.

${ }^{28}$ Hexen, Katalog zur Ausstellung, 44. 
targiert. "So war in Köln von 1627 bis 1630 jede dritte verbrannte Frau eine Hebamme." 29 Warum aber waren es gerade diese Frauen, die als Hexen verschrien und verbrannt wurden? Einen Teil der Antwort darauf finden wir in der Entwicklung der Medizin, parallel zu der Entwicklung der Kirche

Tausend Jahre hindurch war die Hexe der einzige Arzt des Volkes. Die Kaiser, Könige, Päpste, die reicheren Barone hatten einige Doktoren aus Salerne, Mauren und Juden, aber die Masse des gesamten Staates, ja man könnte sagen, die Welt, fragte nur die Saga oder kluge Frau um Rat; wenn sie nicht heilte, beschimpfte man sie und nannte sie Hexe. Aber gewöhnlich belegte man sie aus einem mit Furcht gemischten Respekt mit dem Namen "gute Frau" oder "schöne Frau" (belladonna), derselbe Name, den man den Feen gab30.

Mit zunehmenden medizinischen Kenntnissen, die nun nicht mehr auf der Naturhellkunde der weisen Frauen beruhten, sondern auf wissenschaftlichtheoretischen Erkenntnissen aufgebaut waren, wurden die ehemaligen Heilerinnen verfolgt und verdrängt, um der neuen Wissenschaft Platz zu machen.

... the women accused in the trials were predominantly the wise women, healers and midwives of peasant society, persecuted because they represented a threat to the Church's control and competition to the nascent male medical profession of the early modern period. 31

29 Ingeborg Weber-Kellermann, Erauenleben im 19, Jahrhundert (München: C.H.Beck'sche Yer laksbuchhandlung, 1983) 86.

30 Jules Michelet, Die Hexe, Deutsche Ausgabe (Leipzig: n.a., 1863) 20.

31 Ritta Jo Horsley and Richard A. Horsley, "On the Trial of the 'Witches': Wise Women, Midwives and the European Witch Hunts," Women in German Yearbook 3, ed. Mar ianne Burkhard and Edith Waldstein (Lanham: University Press of Amer ica, 1986) 1. 
Der Hexenhammer schrieb: "Niemand schadet dem katholischen Glauben mehr als die Hebammen"32, weil sie nicht nur über alle möglichen

Kräuterheilmittel verfügten, sondern auch of fen Abtreibungen vornahmen 33

Die Hebammen wurden jedoch nicht so sehr deshalb angeklagt, sondern weil

sie ihre Künste nicht unter dem Mantel der Kirche, sondern unabhàngig davon trieben.

Witches were punished primarily for entering into an agreement with the Devil to deny the Christian God, not for raising a storm to damage the crops or for bewitching a neighbor's baby to death. 34

Auch die ehemalige Dualität der Rolle der Heilerinnen wurde im Zuge der

Christianisierung der heidnischen Völker verwandelt.

The ambivalence towards appraising woman's status - at an earlier time the evaluation fluctuated between magical awe and fear - now appears ideologically displaced in the two distinct images of virgin and witch. Woman was "divided": based on the dogma of the duality of body and soul (in which the body stands for the evil, worldy/natural principle, the soul for the good, spiritual principle), the witch became the incarnation of the sins of the flesh, of female sexual functions, of tota mulier sexus 35

Diese einseitige Verteufelung der ehemaligen weisen Frauen machte sich auch dar in bemerkbar, wie inr Äußeres im Laufe der Zeit immer mehr stigmatisiert wurde.

\section{Der Hexenhammer.}

33 "im Hexenhammer zum Beispiel werden die Hebammen gerade wegen der Anwendung von Zauber mitteln gegen Fruchtbarkeit (oder für Impotenz) und wegen Abtreibung angek lagt." Bovenschen, 82. Siehe auch Barbara Ehrenreich, Witches. Midwives and Nursps, (New York: Feminist Press, 1973).

34 Robbins, 550.

35 Bovenschen, 103. 
Diese einseitige Verteufelung der ehemaligen weisen Frauen machte sich auch dar in bemerkbar, wie inr Äußeres im Laufe der Zeit immer mehr stigmatisiert wurde.

The idea of a witch as a heretic (discussed in the entries for Trials and witchcraft), which was responsible for the judicial murder of thousands in western Europe in the years between 1500 and 1700, did not lend itself to pictorial representation. More easily, the mind's eye conceived, as an embodiment of evil, a woman "old, lame, blear-eyed, pale, foul, and full of wrinkles" (-Reginald Scot). Since the majority of accused witches were women, this concept predominated and took hold in words and illustrations, coming down to modern times in the creations of Walt Disney. 36

Die Hexe wurde also immer mehr zu dem Bild, wie wir es heute in den Märchen finden. "Ugliness came to be a sign or indication I indiciumt of witchcraft." 37

Zu der Zeit, in der die Brüder Grimm inre Märchen sammelten, war das Bild der Hexe schon relativ gefestigt, jedoch noch nicht als feststehender Typ fixiert

During the seventeenth century, the storybook caricature was created from the pictorializations of the idea in contemporary French and German treatises and in the English pamphlets. 38

Natürlich waren sich die Brüder Grimm der Hexenprozesse bewußt. Immerhin fand die letzte Hexenverbrennung in Deutschland erst 1775 statt. Und durch inr außerordentliches Interesse an ehemaligen deutschen Mythen und deren

36 Robbins, 541.

37 Robbins, 541.

38 ebda, 542. 
Auswirkung auf die gegenwärtige deutsche Kultur wußten sie auch von den

Zauberinnen der heidnischen Kulturen und deren Verbindung mit den

mittelalterlichen Hexen.

Jacob Grimm had already recognized the traces of cult processes in the witches' sabbath, even though the former existence of matristic cultures could not have been known to him at that time. ${ }^{39}$

Jedoch sah Jacob Grimm in den Hexen des Mittelalters keine bewußt verfolgte Gruppe, sondern mehr eine zurällige Begebenheit.

... auf einer mischung natürlicher, sagenhafter und eingebildeter zustände beruht die ansicht des mittelalters von der hexerei. Phantasie, tradition, bekanntschaft mit heilmitteln, armut und müssiggang haben aus frauen zauberinnen gemacht. 40

39 Bovenschen, 101.

40 Jacob Gr imm, Deutsche Mythologie, Zweiter Band (Darmstadt: Wissenschaftliche Ver lagsbuchhandlung, 1965) $867 \mathrm{ff}$. 


\section{DIE HEXE IM MÄRCHEN ALS WARNUNG FÜR KINDER}

Bestent nun eine Verbindung zwischen der Hexe, wie sie in den Marchen porträtiert wird, und dem Hexenbild des Mittelalters? Einige Gelehrte, unter innen besonders Psychologen, sehen keine solche Verbindung. Für sie ist das Bild der Hexe schlicht die Ausgeburt der Phantasie eines jeden Kindes, das Angst hat, von der eigenen Mutter gefressen zu werden.

Hänsel and Gretel come face to face with these their fantasies about the devouring mother as they encounter them in the form of the witch ... Harsh events force them to learn to defeat evil incarnate: the witch. 41

Bette theim vergißt jedoch, daß die Märchen nicht von Kindern, sondern von Erwachsenen erzählt und geschrieben wurden, und ein Teil davon, die sogenannten Zaubermärchen, ein ganz bestimmtes Ziel hatten.

Wir erzählen den Kindern liebliche Märchen zur Ermunterung(. . ) : aber um sie abzuhalten schreckliche, wie jene von der Lamia, der Gorgone, von Ephialtes und Mormolnk*).

*) Lamia eine Frau welche Kinder fraß. Gorgone eine Frau mit Schlangenhaaren, ehernen Händen und Zähnen, 50 groß wie Eberhaver; 42

Wie schon im ersten Kapitel erwähnt, waren die Brüder Grimm und Bechstein ein Produkt inrer Zeit, in der christliche Moralvorstellungen den Rahmen für akzeptables Benehmen für Erwachsene wie auch für Kinder bildeten. Die Märchen wurden sowohl als Unterhaltung wle auch als Muster

${ }^{41}$ Bruno von Bettelheim, "Fairy Tales as Ways of Knowing," Eairy Tales as Woys of Knowing, ed. Michøel M. Metzger ond Kothar ino Mommsen (Bern: Peter Lang Publishers Ltd., 1981) $13 \mathrm{ff}$.

42 KHM, Band 3, 273. 
...folk lore scholars have recognized that one special set of stories, so-called scare and warning tales, are meant for children. Tales such as "The Wolf and the Seven Young Kids," "Hansel and Gretel," and "Red Riding Hood" are considered to be educational. In these, children are exposed to hostile powers without the protection of adults. ... In an age when fright was regarded as the most effective disciplinary measure, it was necessary to keep children well-behaved, quiet, at nome and out of trouble. Chlld-devouring witches and ogres that lurked in the forest came in handy and were at the same time pedagogically acceptable, esp. if conveyed through the poetic language of the tale. 43

Im nächsten Kapitel werde ich einige Märchen der Brüder Grimm sowie einige Märchen Bechsteins genauer auf das spezifische Vorkommen der Hexe untersuchen. Ich werde dabei einerseits versuchen, festzustellen, ob und inwiefern Parallelen zu den vorchristlichen Zauberinnen noch aufzufinden sind, und andererseits, welche Botschaften das spezifische Vorkommen der Hexe in den jeweiligen Märchen für Kinder hat

43 Linda Degh, "Grimm's Household Iales and Its Place in the Household: The Social Relevance of a Controversial Classic," Eairy Tales as Ways of Knowing, ed. Michael M. Metzger and Katharina Mommsen (Bern: Peter Lang, Inc. , 1981) $31 \mathrm{ff}$. 


\section{KAF'TEL HI}

\section{DIE HEXE IMMÄRCHEN}

Obwohl die Hexe bestimmt eine der erinnerungswürdigsten und eindrucksvollsten Gestalten des Märchens ist, kommt sie tatsächlich weit weniger häufig vor, als man wegen des starken Eindrucks, den sie auf den Leser macht, annehmen sollte. In den ganzen 211 Texten der Brüder Grimm tritt sie nur ca. fünfzigmal in Erscheinung, und das längst nicht immer in der Rolle der bösen Hexe, sondern überwiegend in der Rolle der Stiefmutter.

Zwanzigmal finden wir sie als weise Frau in mehr oder weniger bösartiger Form vor, und auch bei Bechstein ist sie bei weitem nicht die Hauptfigur. Um es jedoch nicht nur bei leeren Zahlen zu belassen sei bedacht, daß viele dieser Hexengestalten in ein- und derselben Erzählung auftreten. Somit enthalten nicht etwa ein Viertel aller Grimmschen Erzählungen eine Hexe, sondern viele Märchen handeln gleichzeitig von einer Hexe und deren Tochter, die dadurch automatisch auch zur Hexe wird. Hexen findet man deshalb auf nur ungefähr dreissig verschledene Erzählungen verteilt. Obwohl also insgesamt nur etwa vierzehn Prozent aller Grimmschen Märchen von Hexen handeln, ist die Hexe doch eine der ersten Figuren, die einem in den $\operatorname{Sinn}$ kommen, wenn man nach Märchengestalten gefragt wird.

Fällt das Wort "Hexe", so denkt auch ein jeder von uns wahrscheinlich zunächst an die Märchenhexe, die uns aus Kindertagen wohlvertraut ist: an jenen Typus der alten Frau mit rotgeränderten Triefaugen und krummer Nase, die gebückt am Stock einherhumpelt, auf deren 
Schulter ein schwarzer Rabe oder Kater hockt.... Eine andere Form der Märchenhexe ist die böse Stiefmutter, deren abgrundtiefer $\mathrm{Haß}$ sich gegen ganz bestimmte Personen, besonders gegen ihre Stiefkinder richtet. Das Märchen zeigt uns also das Böse - ohne Mitwirkung des Teufels - in Gestalt der Hexe, einer negativ gezeichneten Frau von ausgesprochener Häßlichkeit, die aus Gier, Bosheit, Neid und Haß inren unschuldigen Opfern um jeden Preis Schaden zufügen will."

Tatsächlich wird das Wort "Hexe" bei den Brüdern Grimm und bei Bechstein fast wie eine Beruf sbezeichnung verwendet und bedeutet in den Marchen beinahe immer: des bösen Zaubers kundig. Ob Stiefmutter, Alte im Wald, Zauberin oder Hexe, fast alle der dominanten Frauengestalten erscheinen als ausschließlich böse und schädigend.

Die Verwendung des Wortes Hexe als Berufsbezeichnung, Bezeichnung für eine Frau, die des bösen Zaubers kundig ist, entspricht zwar dem Gebrauch des Wortes in der Zeit der Hexenverfolgung, umfaßt aber nie die Weite, die dieser Begriff früher meinte, denn die "Hexen" alter Zeiten haben helle und dunkle Aspekte gehabt, d.h. guten und bösen Zauber geübt, Kräuter heilend und krankmachend oder tötend verwendet 2

Wie schon in Kapitel II erläutert, wurde dieser dualistische Aspekt der weisen Frau durch die Hexenverfolgung des Mittelalters einseitig zur negativen Seite hin verlagert, und ist so auch überwiegend in den Märchen erhalten. Die Künste der Hexen bestehen weitgehend in den üblen Taten, die den angek lagten Frauen in der Zeit der Hexenverfolgung nachgesagt wurden. Sie sind kräuter-und giftkundig und innen wird vorgeworfen, Menschen und Tiere zu vergiften. In den Märchen Das Rätsel, Die sechs Schwäne und

I Waltrout Jilg, "Der Begr iff "Hexe" und seine Komplexität," Ieufelsalaube und Hexenprozesse, Hrsg. Georg Schwaiger (München: Beck, 1987) 38.

2 Elisobeth Müller, Das Bild der Frau im Märchen (München: Profil-Verlog, 1986) 45. 
Sneewittchen erschetnen jewells giftkundige Hexen. Die Hexe in Der Krautesel kann Brech-und Schlafgetränke herstellen.

Ein weiterer Vorwurf ist, daß sich Hexen in Tiere und Gegenstände verwande in sowie andere Menschen verzaubern können. In Jorinde und Joringe/ verwandelt sich die Hexe in eine Katze und Nachteule, die Mädchen in Vögel. In Weiße und Schwarze Braut verwandelt die Hexe inre Stief tochter in eine Ente. In Brüderchen und Schwesterchen verzaubert die Stiefmutter das Brüderchen in ein Reh.

Die Vorwürfe der Inquisition, daß Hexen Menschen verzehren, finden inren Wiederhall ebenfalls in den Märchen. In Hänsel und Gretel, Fundevogel, Der Liebste Roland, Lammohen und Fischchen und in Bechsteins Vom Knaben. der das Hexen lernen wollte entsteht jeweils eine Situation, in der die Hexe zumindest vorhat, Menschen zu essen, obwohl es nur in Machandelboom tatsächlich dazu kommt.

Es ähneln jedoch nicht nur die Hexenkünste der Märchen denen des Hexenhammers, sondern auch die Strafen, die den Hexen des Märchens zugeteilt werden, gleichen denen, welche die Inquisition an den Hexen vollzog. Die meisten Hexen werden am Ende verbrannt (so in Briderchen und Schwesterchen, Hänsel und Gretel, Die sechs Schwäne, Der Trommler), zwei werden ertränkt (Drei Männlein im Walde, Fundevogel), elne erhängt (Das blaue Licht), eine durch einen Mühlstein erschlagen (Machandelboom) und eine Im wald von wilden Tieren zerrissen (Bruderchen und Schwesterchen). Viele werden zu Tode gefoltert. So wird die Hexe in weiBe und Schwarze Braut und in Drei Männlein im Walde in einem nagelbeschlagenen Faß zu Tode gerollt, wănrend sle in Die zwölr Brider in ein Faß mit sledendem öl 
und giftigen Schlangen gesteckt wird. In Sneewittchen und Der Liebste Roland muß sie sich auf glühenden Kohlen zu Tode tanzen.

Auch das Aussehen der Hexe des Märchens zeigt Parallelen zu dem der Hexe des Mittelalters, obwohl man erkennen muß, daß das typische Hexenbild der Hexe mit roten Augen, spitzer Nase und Buckel erst in den Märchen krelert wurde. Erstaunlich ist jedoch, daß unser heutiges Hexenbild, wie oben erwännt, nicht von den Brüdern Grimm zu stammen scheint, sondern von Bechste in. So beschreiben die Brüder Grimm das Aussehen der Hexe nur relativ selten. Sie ist meistens eine "alte krumme Frau" (KHM 69)3 oder "eine steinalte Frau, die sich auf eine Krücke stützte" (KHM 15), sie hat "große rote Augen, krumme Nase, die mit der Spitze ans Kinn reichte" (KHM 69), sie lacht "boshaft", spricht "höhnisch" (KHM 15) und schleicht "heimlich, wie die Hexen schleichen" (KHM 11).

Darüber hinaus wird sie bei den Brüdern Grimm nicht weiter beschrieben. Bei Bechstein Jedoch wird sie bis ins kleinste Detail skizziert:

Da ging die Tür des Häusleins auf, und trat ein steinaltes, krummgebücktes Mütterlein heraus von nicht geringer Häßlichkeit, Gesicht und Stirne voll Runzeln und in mitten eine große, große Nase. Hatte auch grasgrüne Augen.... Es hatte aber mit der Aiten ein gar schlimmes Bewenden. Sie war eine böse und garstige Hexe, welche die Kinder $\mathrm{fraß}$, die sie durch inr Brot-und Kuchenhäuslein anlockte, nachdem sie sie erst recht fett gefüttert. (Hänse) und Grete), DMB \&) Ein weiteres Märchen, Die Hexe und die Königskinder, das an das Märchen von Hänsel und Gretel erinnert, wurde von Bechstein für die 53er Ausgabe völlig neu erzähit. Ich zitlere hier nur den Anf ang als Beisplel für Bechsteins Ausschmückungen und seinen Hang zum Übertreiben.

3 Der leichteren Veständlichkeit wegen werde ich von nun an sowohl den Titel als auch die KHM Nummerierung verwenden. 
Mitten in einem Walde wohnte eine alte schilmme Hexe ganz allein mit inrer Tochter, welche letztere ein gutes, mildes Kind war, und bei der das Sprüchwort [sic]: der Apfel fällt nicht weit vom Stamme, nicht zutraf. Der Stamm nämlich war über alle Maßen knorrig, stachlich und häßlich; wer die Alte sah, ging inr aus dem Wege, und dachte: Weit davon ist gut vom Schuß. Die Alte trug beständig eine grüne Brille, und über inrem Zot telhaar, das ungekämmt inr vom Kopfe weit herunter hing, einen roten Tuchlappen, und ging gern in kurzen Ärmeln, daß ihre dürren wettergebräunten Arme weit aus dem sie umschlotternden Gewand hervorragten. Auf dem Rücken trug sie für gewöhnlich einen Sack mit Zauberkräutern, die sie im Walde sammelte, und in der Hand einen großen Topf, darin sie dieselben kochte, und damit Ungewitter, Hagel und Schlossen, Reif und Frost zu Wege brachte, so of tes inr beliebte.

Bechsteins Beschreibungen ähneln viel mehr denen der Hexenbeschreibung der Zeit des Hexenhammers ${ }^{4}$, als die sehr viel kärgeren Ausführungen der Brüder Grimm, sodaß die Vermutung naheliegt, daß unsere heutige Vorstellung der Hexe, wie sie Waltraut Jilg eingangs beschrieb, sowohl mit der tatsächlichen Darstellung im Märchen, als auch mit unserer eigenen Phantasie zu tun hat; wie denn auch Bechstein, als er dieses Märchen neu erzählte, seiner Phantasie freien Lauf ließ, während die Brüder Grimm so wenig wie möglich ausschmücken wollten.

So findet sich auch bei den Brüdern Grimm keine Stelle, an der die Hexe tatsächlich Kräuter mischt oder sammelt. Der einzig direkte Bezug zu der Hexe in Verbindung mit Kräutern ist in Rapunzel, wo die Zauberin einen Garten besitzt, der "voll der schönsten Blumen und Kräuter stand" (KHM 12). Wiederum ergibt sich hier die Vermutung, daß die Hexe als Kräuterfrau mehr aus der Erinnerung an frühere Zeiten und aus der Verbindung der Märchenhexe mit Wald und Natur in der Phantasie des Lesers entsteht, als aus konkreten

\footnotetext{
4 siene Kapitel 2.
} 
Erzăhlungen.

Obwohl also von den heil-und pflanzenkundigen Frauen früherer Zeiten im Märchen wenig übriggeblieben ist, ist die Erinnerung an sie stark genug, daß die weisen Frauen doch noch vereinzelt, wenn auch in subtilerer form, erscheinen. Die Hexe selbst tritt zwar überwiegend als durchweg böse Frau auf, sie kommt jedoch teilweise auch in ihrer dualistischen form als sowohl gute als auch böse Frau vor (siehe Frau Holle u.a.). Begrenzt erscheint sie auch als nur gute Helferin.

Ich möchte deshalb im folgenden zwischen den verschiedenen Märchenhexenkategorien "Böse Hexe", "Stiefmutter", "Zauberin", "Hexe als gute/böse Frau" und "Helferin/Weise Frau/Gute Fee" unterscheiden und zu jeder Kategorie ein Beispiel näher untersuchen. Die Untersuchung wird nach den folgenden Gesichtspunkten erfolgen:

1. Erzählung des Märchens und Quellennachweis 5

2. Veränderungen und Vergleich zwischen Bechstein und den Brüdern Grimm, wenn möglich

3. Rollenverhalten der Hexe

4. Auswirkung auf Leser, respektive Leserinnen

5 Zum Quellennachweis benutze ich die folgenden Texte: Jacob und Wilhelm Grimm, Kinder und Hausmärchen, Band 3 (Stuttgart: Philip Reclam Jun., 1983) (KHM, Band 3), Johannes Bolte und Georg Polivka, Anmerkungen zu den "Kinder - und Hausmärchen", 5 Bände 1913-32 (Hildesheim: Georg Olms, 1963) (Bolte), Ludwio Bechstein. Sämtlliche Märchen (Bechstein), (München: Winkler Verlag, 1985) und Ingrid Spörk, Studien zu ausoewählten Märchen der Brüder Grimm, 2. Auflage (Königstein/ Ts: Verlag Anton Hain Meisenheim GmbH, 1986). 


\section{DIE BÖSE HEXE}

Wie schon erwähnt, kommt die Frau als böse Hexe, d.h. in der Rolle der alten Frau, die alle in lebt und üble Machenschaften spinnt, weniger of t in den Märchen vor, als man annehmen möchte, und wenn, dann meist nur als Auslöser für die eigentliche Handlung. Sie ist nie eine eigenständige Persönlichkeit, sondern erscheint fast als Karikatur, indem inre negativen Seiten einseitig übertrieben sind, und sie keinerlei positive Qualitäten vorweist. Ihre Hauptattribute sind, daß sie im Wald wohnt, meistens allein, daß sie von Tieren begleitet wird und sich in Tiere verwande In kann, daß sie Menschen aus Böswillen gefangennimmt und verzaubert. Am Ende wird sie immer bestraft. In diese Kategorie fallen die Hexe in Frau Trude (KHM 39), Jorinde und Joringel (KHM 69), Das blaue Licht (KHM 116), Die Alte im wald (KHM 123) und natürlich Hänsel und Gretel (KHM15). Alles in allem gibt es also nur fünf solcher Vorkommnisse, während in allen anderen Märchen die böse Frau in einer weiteren Rolle z.B. alsStiefmutter, Zauberin, etc. auf tritt.

Ich möchte an Hand der Geschichte von Hänsel und Gretel diese Kategorie etwas näher untersuchen, setze jedoch voraus, daß dieses Märchen so gut bekannt ist, daß es hier nicht weiter erzählt werden muß.

\section{Hänsel und Gretel}

1. Zur Quelle dieses Märchens ist zu sagen, daß es in seiner ursprünglichen Fassung Brüderchen und Schwesterchen hieß und sehr viel kürzer war als die Fassung von 1812. Die Brüder Grimm selbst geben als Quellennachweis "nach verschiedenen Erzählungen aus Hessen" mit der 
Addition des Zuckerhauuschens und der später eingefügten Antwort der Kinder auf die Frage der Hexe: "Knuper, knuper kneischen, / Wer knupert an meinem Häuschen?" "Der Wind, der Wind, das himmlische Kind"6.

2. Zur Textveränderung ist zunächst allgemein zu sagen, daß die Fassung von 1812 sehr viel länger und ausgeschmückter ist, als die ursprüngliche Version von 1810. Was die Hexe selbst betrifft, so ändert sie inr Aussehen und ihr Verhalten im Laufe der verschiedenen Fassungen, während sich gleichzeitig das Verhältnis der Kinder zu der Hexe verschiebt. In der 1810 version "erschraken die Kinder sehr", nachdem die Hexe sie angerufen hatte und hörten auf zu essen.

Bald darauf kam eine kleine, alte Frau heraus, die nahm die Kinder freundlich bei der Hand, führte sie in das Haus und gab innen gutes Eßen und legte sie in ein schönes Bett.

Hier erscheint die Hexe zunächst eher als Lebensspenderin, weil Nahrunggebende, denn als Todbringerin. Sie ist klein von Gestalt, also das Gegenteil von furchterregend, und ist freundlich zu den Kindern. Im Gegensatz zu der Mutter, die die Kinder von sich schickte, nimmt die Hexe die Kinder bei sich auf, gibt innen Essen, was zu Hause knapp war, und schafft innen eine angenehme Schlafstatt. Zudem wird sie nicht als Hexe tituliert, sondern als "kleine, alte Frau", was eine weitere Verharmlosung der Gestalt darstellt.

In der 1812 Version nimmt die Hexe schon hexenähnlichere Züge an. Während die Kinder ruhig weiteressen, geht die Tür auf,

... und eine steinalte Frau, die sich auf eine Krücke stützte, kam herausgeschlichen. Hänsel und Gretel erschracken so gewaltig, daß sie

6(KHM, Bana 3, 25). 
fallen ließen, was sie in den Händen hielten. Die Alte aber wackelte mit dem Kopfe und sprach >ei, ihr lieben Kinder, wer hat euch hierher gebracht? kommt nur herein und bleibt bei mir, es geschieht euch kein Leid. S Sie faßte beide an der Hand und führte sie in inr Häuschen. Da ward gutes Essen aufgetragen, Milch und Pfannekuchen mit Zucker, Äpfel und Nüsse. Hernach wurden zwei schöne Bettlein weiß gedeckt, und Hänsel und Gretel legten sich hinein und meinten, sie wären im Himmel. Die Alte hatte sich nur so ireundich angestellt, ste war aber eine böse Hexe, die den Kindern auflauerte, und hatte das Brothäusle in bloß gebaut, um sie herbeizulocken. Wenn eins in ihre Gewalt kam, so machte sie es tot, kochte es und aß es, und das war ihr ein Festtag Die Hexen haben rote Augen und können nicht weit sehen, aber sie haben eine feine witterung, wie die Tiere und merkens, wenn Menschen herankommen.

Offensichtlich bastelten die Brüder Grimm hier an dem Bild der Hexe, um es für Kinder erschreckender und damit erzieherisch wirksamer zu machen. Und offensichtlich gleicht das Bild der Hexe in dieser Version sehr viel mehr der Beschreibung der Hexe des Mittelalters und unserer heutigen Auffassung. Aus der alten, kleinen Frau wird eine "steinalte" Frau und die obligatorische Krücke wird erwähnt. Dazu passt auch der wackelnde Kopf und der schleichende Gang. Auch wird hier zum ersten Mal erwähnt, daß die Alte in Wirklichkeit eine Hexe ist, und was das bedeutet, wird aufs grimmigste geschildert: Kinder werden bewußt angelockt, gefangengenommen und gefressen, und das ist den Hexen auch noch ein Festtag! Eine weitere neue Einführung sind die roten Augen der Hexe, mit denen sie nicht viel sehen kann. Kurioserweise gibt diese Blindheit der Hexe einen fast hilf losen und abhängigen Anstrich, was im Gegensatz zu der tötenden, machtvollen Position der Hexe steht. Auch wird die Hexe hier in Verbindung mit Tieren gebracht, da sie eine "feine Witterung" hat, die sie Menschen riechen anstatt sehen lässt. 
Im weiteren Verlauf des Märchens schmücken die Brüder Grimm die ursprüngliche Version hauptsächlich durch Stilmittel, wie direkte Rede und Attribute, aus, sle bringen im wesentlichen jedoch keine weiteren Veränderungen an, mit Ausnahme eines christlichen Elements, in dem Gretel Gott um Hilfe anfleht, und die Hexe eine "gottlose" Hexe wird. Bechsteins Version, wie schon oben erwähnt, kreiert ein noch typischeres Hexenbild, indem er der Hexe noch stärkere Attribute verleit.

..trat ein steinaltes, krummgebücktes, triefäugiges Mütterlein heraus von nicht geringer Häßlichkeit, Gesicht und Stirne voll Runzeln und in mitten eine große Nase. Hatte auch grasgrüne Augen.

Hier wird das Alter und die Häßlichkeit der Hexe noch extra betont, im Großen und Ganzen jedoch, unter Auslassung des christlichen Aspekts, folgt Bechsteins Version der Grimmschen Version von 1812.

3. Zur grundsätzlichen Rolle der Hexe sei zunächst ein kurzer Überblick über das Rollenverhalten der Märchencharaktere allgeme in im Hinblick auf Vladimir Propps Strukturanalyse der Märchen gegeben. In seiner Untersuchung fand Propp, daß alle Märchen dieselbe Struktur aufzeigen. Er fand weiterhin zwei immerwiederkehrende Grundzüge, wobei der eine mit der Funktion der Charaktere zu tun hat und der andere mit der Verteilung der Rollen. Funktion wird bei Propp verstanden als die Handlung eines Charakters, die im Hinblick auf ihre Wichtigkeit für den weiteren Handlungsablauf bestimmt wird. Er unterscheidet einunddreissig solcher Funktionen, die sieben "Handlungssphären" zugeordnet werden, die wiederum durch die folgenden Rollen gekennzeichnet sind?:

7 zur weiteren Erläuterung siehe Vladimir Propp, Morohologo of the Folktale, trans. Laurence Scott (Austin: University of Texas Press, 1968). 
1. Der Bösewicht8

2. Der Spender (Geber magischer Hilfsmittel)

3. Der Helfer

4. Die Prinzessin (oder die gesuchte Person) und inr vater

5. Der Uberbringer

6. Der Held

7. Der falsche Held

Propp sient zwar, daß diese Rollen sich teilweise decken, aber nur zu einem gewissen Grad. "Ein Charakter kann verschiedene Rollen annehmen; eine Hexe, zum Beispiel, kann zugleich als Bösewicht, feindlich gesinnter Spender oder unfreiwilliger Helfer fungieren"9, sie kann jedoch nie zum Helden, d.h. zur Zentralfigur des Märchens werden. Propp wurde verschiedentlich in seiner Strukturanalyse kritisiert, unter anderem von Levi-Strauss und A. J. Greimas, die in Märchen mehr einen Konflikt zwischen dem Helden und seinem Gegner sahen. So meint auch Tatar:

This dichotomy between helpers and adversaries seems indeed to be as basic to the fairy tale as the persistent binary opposition between good and evil, weak and strong, humble and royal, young and old, familiar and alien. ...his adversaries--whether they take on the shape of cunning witches, plotting stepmothers, or foxy chambermaids-retain eminently human features. 10

Egal in welcher Gestalt die böse Frau auftritt, sie fungiert hauptsächlich als

8 Deutsche Übersetzungen von dem Verfasser.

1. The villain, 2. The donor (provider of magical agents), 3. The helper, 4. The princess (orsought-for-person) and her father, 5. The dispatcher, 6. The hero, 7. the false hero.

9 "One char acter may take on multiple roles; a witch, for example, can figure at once as a villain, a hostile donor, or as an involuntary helper," Tatar, $82 \mathrm{ff}$.

10 Tatar, 85 
Nebenfigur und Katalysator einer bestimmten Situation, anstatt als eigenständige Persönlichkeit. Sie dient dazu, die Handlung vorwärtszutreiben, entweder durch inre eigenen bösen Intentionen, oder indem sie dem Helden/der Heldin durch ein Geschenk weiterhilft.

In Hänsel und Gretel erscheint die Hexe zunächst als Lebensspenderin und Nahrunggebende, indem sie die Kinder bei sich aufnimmt. Sie zeigt sich jedoch sehr schnell in ihrer wirklichen Gestalt, der menschenfressenden Hexe. Nicht nur ernährt sie sich von Menschenfleisch, sie schmiedet sogar Pläne, wie sle ihre Opfer anlocken kann, indem sie ein Zuckerhaus aufstellt und damit an die Naschnaftigkeit von Kindern appelliert. Sie zeigt sich hier in einer aktiv Pläne schmiedenden Rolle, die sehr an die Rolle der "Großmutter Spinne" indianischer und afrikanischer Märchen erinnert. Mythologisch finden wir hier ein Überbleibsel der Form der Großen Göttin oder Urmutter, die als allesverschlingende dunkle Macht erscheint.

Beim hexenmahl werden gewöhnlich knaben geschlachtet, gesotten oder gebraten und aufgezehrt. das erinnert an altheidnische und riesische gebräuche dies schlachten, kochen und essen der kinder ist uralter wesentlicher zug. 11

Es läßt sich hier vermuten, daß die Brüder Grimm, bekannt mit Mythologie, in ihrer menschenfressenden Hexengestalt Züge alter Fruchtbarkeitsriten, in denen ein männliches Opfer als Zeichen der 'Heiligen Heirat' zwischen inm und der Großen Göttin symbolisch geschlachtet wurde, um die Erde fruchtbar zu machen 12 , in ihre Märchen aufgenommen haben.

11 Jacob Grimm, Deutsche Mythologie, Dritter Band (Darmstadt: Wissenschaftliche Ver lagsbuchhandlung, 1965) 312.

12 siehe Robert Graves The White Goddess (New York: Farrar, Straus \& Giroux, 1948). 
4. Zusammenfassend sei erwähnt, daß in den fünf oben genannten Märchen die Hexe jeweils im Wald auf inr Opfer lauert, daß sle an der Beseitigung inres Opfers arbeitet, und daß sie am Ende für inre Bosheit mit dem Tod bestraft wird (mit Ausnahme von Frau Trude). Sie erscheint als eine zu fürchtende, menschenfressende, bösartige Frau, die Schrecken einjagt und der man tunlichst aus dem weg gehen sollte. 
DIE HEXE ALS STIEFMUTTER

Die bei weitem am häufigsten auftretende Hexenkategorie ist die der bösen Stiefmutter. In fast allen Märchen, in denen Hexen vorkommen, wird die Handlung von bösen Stiefmüttern und nur selten von bösen Vätern ausgelöst 13, und fast immer ist es eine Situation, in der der Konflikt zwischen der guten Tochter und der bösen Stiefmutter besteht. In diese Kategorle zählen Die 12 Brudder (KHM9), Bruderchen und Schwesterchen (KHM 11), Die drei Männlein im Wald (KHM 13), Hänsel und Gretel (KHM 15), Achenputtel (KHM 21), Frau Holle (KHM 24), Van den Machandelboom (KHM 47), Die sechs Schwàne (KHM 49), Sneewittchen (KHM 53), Der Liebste Roland (KHM 56), Die weiße und die schwarze Braut (KHM 135), Die wahre Braut (KHM 186), Die Goldmaria und die Pechmaria (DMB (1), Schneeweischen (DMB 51), Aschenbrödel (DMB 62), Der wacholderbaum (DMB 66) und vom Knäblein, vom Mägle in, und der bósen stiermutter (DMB 64a). Was aber sind die Gründe des Handelns der Stiefmütter und wie wirkt sich das auf den Verlauf der Erzählung selbst aus?

In den meisten Märchen wird die Handelsweise der Stiefmutter durch reine Bosheit, Gier oder Misgunst ausgelöst. Meist existiert eine Tochter der Stiefmutter, die schon allein well sle die lelbliche Tochter ist auch böse und falsch ist. Bevorzugung des eigenen Kindes und Vernachlässigung der Stiefkinder gehören ebenfalls zum Motiv der bösen Stiefmutter. Meist hat

13 für einen Vergleich zwischen Vätern und Müttern als Auslöser siehe Elisabeth Müller, Das Bild der Frau im Mörchen (München: Profil-Ver log, 1986). 
der Vater keinen oder kaum Einfluß auf das Treiben der Stiefmutter den Kindern gegenüber. Stolz, Neid und Haß sind weitere Eigenschaften, die die stretmutter zu inrem bosen Handein verierten. Andere Mate jedocn tunren ökonomische $z$ wänge zu dem verhaiten der Stiefmutter. In einem Märchen, Die sechs Schwäne, wird der Stiefmutter von vornehere in keine Chance als gute Mutter gegeben. Der Konig nimmt automatisch an, daß sie bose ist und sperrt seine Kinder deshalb in ein einsames Schloß mitten im wald. In den Strefmuttermärchen lassen sich hauptsächlich vier Elemente unterscheiden, die sich auf die Stiefmutter selbst beziehen:

1. Die Stiefmutter ver jagt inre Stiefkinder.

2. Die Stiefmutter, manchmal mit Hilfe inrer leiblichen Tochter, will die Stiefkinder töten.

3. Bräute werden vertauscht.

4. Erlösung der Helden und Tod der bösen Frau(en).

Diese vier Elemente ziehen sich in mehr oder weniger abgewandelter Form durch die meisten oben angeführten Märchen. Ich möchte deshalb für jedes Element ein Beispiel stellvertretend analysieren, wobei ich Punkt drei und vier gemeinsam betrachten werde.

\section{Sneewittchen}

Ich gehe wiederum davon aus, daß der Inhalt des Märchens genügend bekannt ist, und hier nicht noch einmal wiedergegeben werden muß.

1. Das Märchen erscheint in der Ölenberger Handschrift unter dem Namen "Schneeweißchen", dem Namen, der bel Bechstein belbehalten wird, während die Brüder Grimm inn in der endgültigen Fassung zu Sneewittchen 
umformen, mit der Bemerkung, "dies Märchen gehört zu den bekanntesten, doch wird in Gegenden, wo bestimmt hochdeutsch herrscht, der plat tdeutsche Name beibehalten, oder auch verdorben in Schliwitchen". 14 Die endgültige Fassung von 1819 ist nach "vielfachen Erzählungen aus Hessen"15 umgearbeitet worden.

2. Die hauptsächlichste veränderung zwischen der Fassung der Ölenberger Handschrift, der von 1812 und der endgültigen von 1819 besteht in der Umänderung der Beziehung der beiden Frauen. In der Ölenberger Handschrift ist die Königin die leibliche Mutter Sneewittchens, die ihre Tochter umbringen will, indem sle sie selbst in den Wald führt.

Wie nun der Herr König einmal in den Krieg verreist war, so ließ sie inren Wagen anspannen $u$. befahl in einen weiten dunklen Wald zu fahren, u. nahm das Schneeweißchen mit. In dem selben Wald aber standen viel gar schöne rothe Rosen. Als sie nun mit ihrem Töchterlein daselbst angekommen war, so sprach sie zu inm: ach Schneeweißchen steig doch aus $u$. brich mir von den schönen Rosen ab! Und sobald es diesem Befehl zu gehorchen aus dem Wagen gegangen war, fuhren die Räder in größter Schnelligkelt fort, aber die Königin hatte [es] alles so befohlen, weil sie hoffte, daß es die wilden Thiere bald verzehren sollten. 16

In der 1812 Version ist die Königin zwar immer noch die leibliche Mutter, bedient sich aber eines Jägers, um sich inrer Tochter zu ent ledigen.

Da ließ ihr der Neid keine Ruhe, und sie rief einen Jäger und sagte zu inm: "führ das Sneewittchen hinaus in den Wald an einen weiten

\footnotetext{
$14 \mathrm{KHM}$, Band 3,99 .
}

15 ebda, 99.

16 Rölleke, 244. 
abge legenen Ort, da stichs todt, und zum Wahrzeichen bring mir seine Lunge und seine Leber mit, die will ich mit Salz kochen und essen." 17 Hier bedient sich die Königin der Hilfe eines anderen, um nicht selbst den Mord ausführen zu müssen, eine Vertiefung inrer Grausamkeit wird jedoch durch das Hinzufügen des Wunsches zur Verzehrung der Lunge und der Leber erreicht. Diese hinzugefügten Zeilen erinnern an die menschenfressende Hexe in anderen Märchen (siehe Hänsel und Gretel) und verleihen der Konigin eine besondere Grausamkeit.

In der Version von 1819 und in der Version Bechsteins sind diese Zeilen denn auch wieder gestrichen, die Königin verlangt nur noch die Lunge und Leber "zum Wahrzeichen, daß du mein Gebot vollzogen!" (Bechstein) Eine entscheidende Veränderung sowohl bei den Brüdern Grimm als auch bei Bechstein besteht darin, daß die Königin nicht mehr die leibliche Mutter, sondern die Stiefmutter ist.

3. In allen Fassungen ist die Königin die Ausschlaggebende, daß Sneewittchen von ihrem rechtmäßigen Platz als Prinzessin im Schioß vertrieben wird und später als gewöhnliche Magd den Zwergen dienen muß. Sneewittchens Verstoßung ist auch keineswegs durch irgendeine Schuld inrerseits ausgelöst worden, sondern erfolgt aus purem Neid und Misgunst der Königin. Diese stellt also eine Gewalt im Leben Sneewittchens dar, die willkürlich ist und gegen die Sneewittchen machtlos ist. Es ist auch nicht genug, daß Sneewittchen dieser Gewalt entkommt, denn sobald die Königin erfährt, daß Sneewittchen noch am Leben ist, sucht sie nach Zaubermittein, mit denen sie ihre Schönheitsrivalin ermorden kann und stellt ihr nach, um sie zu finden.

17 ebda, 245. 
Diese Verfolgung durch die bose Frau splelt eine große Rolle in den meisten der Zaubermärchen und ich werde später bei der Besprechung der Hexe als Zauberin noch näher darauf eingehen

4. Wir haben es in Sneewittchen und in den meisten der StiefmutterMärchen mit einer Frau ännlich der des ersten Typus zu tun, mit einer Frau also. die aktiv Ränke soinnt. um Kindern zu schaden. Nur wirkt die Frau hier sehr viel machtvoller, da sie nicht passiv auf inre opfer wartet, sondern inren Opfern nachstellt. Auch benützt sle dabei Zaubermittel, was diesen Märchen eine erweiterte Dimension des übernatürlichen verleint. Sle erscheint als eine mißgünstige Figur, die nur ihre eigenen Kinder liebt, und auch das meistens nur, weil es inr Vorteile bringt, und die inre Stiefkinder schikaniert und am liebsten los wäre. Dieses Motiv der Vertreibung der Stiefkinder splelt in den anderen Stiefmuttermärchen eine noch größere Rolle als bei Sneewitichen so Z.B. bel Briderchen und Schwesterchen (KHM 11), wo sich das Brüderchen beklagt:

Seit die Mutter tot ist, haben wir keine gute Stunde mehr; die Stiefmutter schlägt uns alle Tage, und wenn wir zu ihr kommen, stößt sie uns mit den Füßen fort. Die harten Brotkrusten, die übrigbleiben, sind unsere Speise, und dem Hündlein unter dem Tisch gent's besser: dem wirft sie doch manchmal einen guten Bissen zu. Daß Gott erbarm, wenn das unsere Mutter wüßte! Komm, wir wollen miteinander in die weite Welt gehen (KHM 11).

Zumeist richtet sich der Zorn und Neld der Stlefmutter jedoch spezlell auf die Stieftochter, die meistens gut und schön ist, während die eigene Tochter als böse und häßlich beschrieben wird. So auch bei Die drei Männlein im Walde (KHM 13), Aschenputtel (KHM21), Frau Holle (KHM 24) U.a. In Drei Männlein im walde nelßt es: 
Die Frau ward ihrer Stieftochter spinnefeind und wußte nicht, wie sie es inr von einem Tag zum andern schlimmer machen sollte. Auch war sie neidisch, weil inre Stieftochter schön und lieblich war, ihre rechte Tochter aber häßlich und widerlich (KHM 13).

Die Gefahr der Verfolgung und der Benachteiligung besteht somit stärker für Mädchen als für Jungen (es gibt kein einziges Märchen, in dem die Hexe einen Sohn und einen Stief sohn hätte), und es gibt tatsächlich auch mehr Märchen, in denen eine direkte Stiefmutter-Stieftochter Beziehung besteht, als eine direkte Stiefmutter-Stiefsohn Beziehung. Wenn der Junge im Märchen von der Stiefmutter direkt bedroht wird, so ist er meist Teil eines Geschwisterpaars oder er hat zumindest die Hilfe und den Beistand eines Mädchens, wie in Hänsel und Gretel (kHM 15). Brïderchen und Schwesterchen (KHM / /) U. Die Stiefmutter wirkt deshalb besonders erschreckend und furchterregend für Mädchen, zumal sich diese oft nicht nur gegen die Stiefmutter, sondern auch gegen ihre Stiefschwestern wehren müssen.

Das dritte Element der Stiefmuttermärchen, in dem die Stiefmutter die Heldin tötet, damit inre leibliche Tochter deren Status einnehmen kann, ist ebenfalls ein weitverbreitetes Motiv und kommt in neun der Stiefmuttermärchen vor. Ich möchte hier als Beispiel das Märchen von der weißen und schwarzen Braut (KHM 135) anführen.

\section{Die weiße und die schwarze Braut}

1. Dieses Märchen erschien zum ersten Mal 1815 als Märchen Nr. 49 mit dem Vermerk: aus dem Mecklenburgischen und Paderbörnischen. ${ }^{18}$ Es basiert jedoch auf einer von Jacob Grimm nacherzähiten Geschichte namens

18 KHM, Band 3, 217. 
Die Goldene Ente. Ein Nationalmärchen des. Alterthums das 1808 in Sagen der bömischen vorzeit aus einigen Gegenden alter Schlößer und Dörfer in Prag erschien.

2. In der Goldenen Entebeginnt die Geschichte damit, daß elnem Bruder und seiner Schwester die Eltern sterben und sie zu inrer Tante in Verpflegung kommen, die ebenfalls eine Tochter hat, während in der Grimmschen Version am Anfang nur von einer Stiefmutter, deren Tochter und der Stief tochter die Rede ist. In beiden Erzählungen begegnet innen eine Gestalt, in der ersten ist es eine alte Frau, in der zweiten ist es "der liebe Gott." Während in der Goldenen Entenur erwännt wird, daß sich die Pflegetochter elfrig um die alte Frau kümmert, wird in der weißen und Schwarzen Brautbetont, daß die Mutter und Tochter beide unfreundlich und hämisch antworten, während sich die Stief tochter artig um Gott kümmert. In beiden Geschichten wird die Stief tochter für ihr Verhalten belohnt, in der ersten werden inr Gaben zuteil, in der zweiten darf sie selbst wählen.

Des andern Morgens war die alte Frau eine schöne Fei [sic] geworden $u$. dankte alle Leuten, aber der Pflegetochter verlieh sie die Gaben, daß, wenn sie weint oder lacht, statt Thränen, Perlen aus inren Augen rollen, ihre ausgekämmten Haare Goldfäden, $u$. ihr Speichel reines Silber seyn sollen. (Die Goldene Ente)

Im Gegensatz dazu belohnt Gott nicht nur das Mädchen, sondern er bestraft auch gleichzeitig die Mutter und ihre Tochter.

Da zürnte der liebe Gott über die Mutter und Tochter, wendete innen den Rücken zu und verwünschte sie, daß sie sollten schwarz werden wie die Nacht und häßlich wie die Sünde. (KHM 135)

Die gute Tochter jedoch wünscht sich Schönheit, einen nie leer werdenden Geldbeutel und das ewige Himmelreich. Bemerkenswert ist, daß aus der 
weisen Frau, die diejenigen beschenkt, die inr gefällig ist, ein strafender, richtender, christlicher Gott wird, der die einen erlöst, während er die anderen verurteilt.

In beiden Erzählungen entbrennt der König, in dessen Dienst der Bruder des Mädchens steht, in Llebe zu dem Mädchen und läßt eine Kutsche für das Mädchen kommen. Eine Bedingung in der Goldenen Entewar, daß das Gesicht des Mädchens immer vor der Luft bewahrt und verschleiert sein müßte, ansonsten die Wunderkraft vergehen würde. Deshalb fahren die Braut, die Pflegemutter und deren Tochter in einer Kutsche, die "besonders gegen allen Luftzug verwahrt war..., wie sle aber die Hälfte zurückgelegt hatten, wurde das Kutschenfenster verbrochen $u$ die Sonnenstrahlen fielen auf die unverschleierte Jungfrau, die sich plötzlich in eine goldene Ente verwandelte u. hinwegflog." (Die Goldene Ente) In dieser Erzählung erscheint die Pflegemutter (sie wird hier auch nicht Stiefmutter, sondern Pflegemutter genannt) als eine Frau, die sich um die beiden Maddchen gleichmäßig bemüht, sie scheint keinen Unterschied zu machen zwischen leiblicher Tochter und Pflegetochter. Es gibt keinerlei Anhaltspunkt dafür, daß sie der Pflegetochter die Heirat mit dem König neldet. Erst als diese durch unvorhergesehene Einflüsse in eine Ente verwandelt wird, denkt die "Muhme" daran, thre eigene Tochter für die "verlorene Schwester" auszugeben.

In der weiBen und schwarzen Braut hingegen planen die Stiefmutter und tochter das Unglück der Heldin von Anfang an, motiviert durch Misgunst und $\mathrm{Haß}$ und unter Zuhilfnahme von Hexenkünsten.

...alle in die Schwarze war eifersüchtig über das Glück, ärgerte sich über alle Maßen und sprach zu inrer Mutter: "Was helfen nun all Eure 
Künste, da ihr mir ein solches Glück doch nicht verschaffen könnt." "Sei still", sagte die Alte, "ich will dir's schon zuwenden." Und durch ihre Hexenkünste trübte sie dem Kutscher die Augen, daß er halb blind war, und der Weißen verstopfte sie die Ohren, daß sie halb taub war. (KHM 135)

Im weiteren Verlauf bringt die Stiefmutter das Mädchen dazu, Stück für Stück inre Kleidung an ihre Stiefschwester abzugeben bis sie nackt ist, und als sie über eine Brücke kommen und die entkleidete weiße Braut sich auf Anraten der Hexe aus dem Wagen beugt, "da stießen sie die beiden hinaus, daß sie mitten ins Wasser stürzte." Anstatt jedoch zu ertrinken verwandelt sie sich in eine "schneeweiße Ente".

In beiden Erzählungen bewirkt die Stiefmutter, daß der König inre leibliche Tochter anstelle der Pflegetochter heiratet, obwohl er in der Grimmschen Version durch die Künste der Hexe verblendet werden muß, und in beiden Versionen erscheint die Ente nachts im Schloß, bis der König sie als seine rechtmäßige Braut erkennt und erlöst.

4. Aus der Muhme der ursprünglichen Version, die es am Anfang gut mit inrer Pflegetochter meint und erst durch eine günstige Gelegenheit zur Verschwörer in wird, wird in der Grimmschen Version eine von Anfang an böse Stiefmutter, die nur auf den Vorteil inrer eigenen Tochter, und damit auf inren eigenen bedacht ist. Sie plant von vorneherein, wie sie ihre Stief tochter aus dem Weg schaffen könnte, und ist sich nicht zu gut, dies gemeinsam mit ihrer Tochter auszuführen.

Der Tod durch Wasser ist eine Todesart, die auch in anderen Stiefmuttermärchen vorkommt und die Grausamkeit der Hexe in den anderen Märchen ist noch größer als hier. So heben die Hexe und inre Tochter in Die drei Männle in im Walde die schlafende Heldin aus dem Bett und werfen sie 
In den vorbelfließenden Fluß, während sie in Brüderchen und Schwesterchen ein so heißes Bad für die Braut vorbereiten, daß sie darin ersticken muß.

Das letzte Element, die Erlösung der Heldin und der Tod der Hexe, ist wiederum allen Stiefmuttermärchen gemein. In allen Märchen, bis auf die Sneewittchenversion Bechsteins, wird die Hexe am Ende für inre bösen Taten bestraft. Ich habe eingangs schon auf die verschiedenen Todesarten hingewiesen, und möchte sie hier deshalb nicht noch einmal wiederholen. Auffällig ist jedoch, daß in den Märchen, in denen es männliche Mittäter gibt, wie z.B. in Zwolr Bruder, Hänsel und Gretel, etc, diese nicht bestraft werden 19, sondern die Strafe sich alle in gegen Frauen richtet. So wird z.B. der Ehemann, der seine Frau öffentlich beschämt und erniedrigt, wie in Konig Drosselbart, am Ende mit keiner slibe deswegen angeklagt, da er es ja zu inrem Besten tat. Und auch der Vater in Hänsel und Gretel, der ebenso daran beteiligt war, die Kinder im Wald auszusetzen, wird am Schluß nicht Destraft, da er auf Anraten seiner Frau und gegen sein eigenes Gewissen handelte. Die Mittäterschaft allein ist demnach nicht schlimm genug für Männer, um bestraft zu werden. Wenn es sich jedoch um Frauen, oder spezirischer um Tochter von Hexen handelt, dann ist das verbrechen der Mittäterschaft groß genug, um sogar mit dem Tod bestraft zu werden. Die Hexentochter in Brüderchen und Schwesterchen handelt selbst kaum, sondern dient nur als Werkzeug fur die bosen Pläne inrer Mutter. Und doch wird sie dafür mit dem Tod bestraft, indem sie in den Wald geführt wird, wo sie von wilden Tieren zerrissen wird. Auch in Die weiße und die schwarze Brauterleidet die leibliche Tochter der bosen Alten am Ende einen

19 Für eine ausführlichere Diskussion dieses Themas slehe Ingr id Spörk, Studien zu ausgewähliten Märchen der Brüder Grimm, und Elisabeth Müller, Das Bild der Frau im Märchen. 
grausamen Tod zusammen mit inrer Mutter, obwohl es elgentlich die Mutter war, die die Pläne spann und ausführte.

In anderen Märchen, in denen die Stiefmütter zusammen mit ihren Töchtern Übel anrichten, wird am Ende sogar nur noch die jüngere Generation bestraft, wie Z.B. in Aschenouttel, wo die Stlefschwestern am Ende inre Augen ausgepickt bekommen, und in Frau Holle, wo die böse Schwester mit Pech übergossen wird, während in beiden Märchen die Mütter, die die eigentliche Handlung auslösten, am Schluß nicht mehr erwähnt werden. Wie schon eingangs erwähnt, ist die Art der Bestrafung besonders grausam und erinnert an die Strafen der Inquisition. Ob durch verbrennung auf dem Scheiterhaufen, mittels glühender Schuhe, in denen sich die Hexe zu Tode tanzen muß, oder durch Zerrissenwerden in mit Nägeln gespickten Fässern oder von wilden Tieren, die Hexen finden ausnahmslos ihr schmähliches Ende. 


\section{DIE HEXE ALS ZAUBERIN}

Es wäre anzunehmen, daß eine der Haupteigenschaften der Hexe inre Hexenkünste seien, mit denen sie sich selbst und andere verzaubern kann Und doch sind es erstaunlich wenige Hexen, die in den Märchen tatsächlich zaubern können oder die als Zauberinnen beschrieben werden. In inrem Buch Grimms Bad Girls and Bold Boys beschreibt Ruth Bottigheimer in einem Kapitel ausführlich, wie wenig die Hexen tatsächlich zaubern. 20 Fast ebenso of t, wenn nicht öfter, sind es die jungen Heldinnen der Märchen, die Zauberkräfte besitzen und sie auch ausüben. Während die Heldinnen jedoch meist nur dann zu inren Zauberkräften greifen, wenn sie von der Hexe bedroht werden oder vor inr fliehen, macht diese von inren Kräften aus Eigensucht und Böswilligkeit Gebrauch. Of tmals ist diese Eigensucht auf den Verzehr von Menschenfleisch in Form eines Jungen gerichtet, der selbst wiederum durch die Kräfte des jungen Mädchens geschützt werden muß. Das Hauptmotiv dieser Zaubermärchen ist also die Beziehung der Hexe zu der Heldin, nebst einem Messen inrer Zauberkräfte, wobei das Mädchen immer aus lauteren Motiven und zum Schutz eines Jungen wirkt, und daher am Ende triumphiert, während die Zauberin aus bösen Motiven heraus handelt und deshalb am Ende bestraft wird.

Frauen wurden schon von jeher mit der Natur in Verbindung gebracht und hatten in vorchristlichen Zeiten, wie in Kapitel I erläutert, durch inr 
Heilwissen und inre Hebammenfunktion Macht über Leben und Tod. Die heilende Seite dieser Macht erscheint in den Märchen nur noch selten. Ich werde später noch näher darauf eingehen.

Die Hebammenfunktion tritt in den Märchen überhaupt nicht menr zu Tage, und die einzige Anspielung darauf erscheint vielleicht in Raponzel, in dem die Zauberin, "die große Macht hatte und von aller Welt gefürchtet ward", einen Garten hat, in dem die schönsten Rapunze in wachsen. Die schwangere Frau bekommt ein solches Verlangen nach innen, daß sie, als sie sie unerreichbar glaubt, dem Sterben nahe kommt. Die Rapunzein zeigen sich hier also als eine lebensspendende Notwendigkeit für die schwangere Frau, die inr denn auch von der Zauber in bewilligt werden. Sie können vielleicht, da sie aus dem Kräutergarten der Zauberin kommen, mit den kräuterkundigen Funktionen der früheren Hebammen in Zusammenhang gebracht werden.

Ansonsten werden die Künste, wie schon erwähnt, von den Zauberinnen hauptsächlich zu schädigenden 2 wecken verwendet. Es gibt jedoch relativ wenige Stellen in den Märchen, in denen konkret beschrieben wird, wie und was genau die Zauber in zaubert. So wird in dem Sneewittchen der Öienberger Handschrift lediglich erwähnt, daß die Königin einen giftigen Kamm und später einen giftigen Apfel zu Sneewittchen bringt, woher sie sie jedoch hat, wird nicht erzählt. Und in der 1812 version steht nur, daß sie einen gif tigen Kamm und Apfel macht(eigene Betonung), näher darauf eingegangen wird auch hier nicht. Erst in der 1819 Ausgabe wird die Hexenkunst der Königin etwas genauer beschrieben: "..., und mit Hexenkünsten, die sie verstand, machte sie einen giftigen Kamm." und weiter: "Darauf ging sie in eine ganz verborgene Kammer, wo niemand hinkam, und machte da einen giftigen, giftigen Apfel." Aber auch hier wird nicht näher darauf 
eingegangen, wie das Vergiften tatsächlich zustande kam. Wir erfahren nur, daß die Königin etwas von Hexenkünsten verstand

Haupsächlich benutzt die Hexe, wle schon erwähnt, ihre Künste dazu, Kinder, vorzugsweise Jungen, einzufangen, um sie zu fressen, und die tatsächilichen verzauberungen geschehen auf der Flucht der Kinder vor der Hexe. Dieses Fluchtmotiv erscheint sowohl in Der liebste Roland (KHM56), als auch in der Fundevogel (KHM 5I), OKerlo (KHM 70a), Die wassernixe (KHM 79), Die zwei Königsk inder (KHM 113), Die wahre Braut (KHM 186), Der Trommler (KHM1 19.3) und bei Bechstein in Der goldene Rehbock (DME 14), D1e Hexe und die königsk inder (DMB 45), Die drei Nüsse (DMB 49a), Helene (DMB 77a) und Vom Knaben, der das Hexen lernen wollte (NDMB 21) viele Forscher sehen in diesem Märchenmotiv eines der ältesten überhaupt, und einige datieren es sogar vor 2500 B.C.21

In all diesen Märchen besteht der Konflikt immer zwischen der Zauber in und den Kindern, und obwohl die Hexe älter und angeblich erfahrener, sowohl als skrupelloser und böser ist, ist es immer das Mädchen, das über größere Zauberkräfte verfügt. So verwandelt das Mädchen Lenchen in Fundevoge/ sich und inren Liebsten dreimal, und dreimal ist die Hexe hilf los dagegen (interessanterweise wird die Hexe hier als Köchin bezeichnet, während sie in einer anderen Fassung als Stiefmutter benannt wird). Zweimal schickt sie den Kindern Knechte hinterher, die nicht wissen, was tun, als sie beim ersten Mal einem Rosenstöckchen und einem Röschen und beim zweiten Mal einer Kirche und deren Krone begegnen. Und selbst als die Köchin den Kindern selbst hinterherläuft, hat sie keinen Erfolg, da 
Lenchen Fundevogel in einen Teich und sich selbst in eine Ente verwandelt Als die Köchin den Teich aussaufen will, kam "die Ente ...schnell geschwommen, faßte sie mit inrem Schnabel beim Kopf und zog sie ins Wasser hinein; da mußte die alte Hexe ertrinken (KHM 51).

Auch in Der Liebste Roland ergent es der Hexe kaum besser. Hier zeigt sich das Mädchen sogar als noch zauberkundiger, da sie die Stief tochter der Hexe ist. Als sie hört, wie die Hexe beschließt, sie zu töten, vertauscht sie nachts Plätze mit ihrer Stiefschwester, sodaß diese an inrer Stelle ermordet wird. Sodann stiehlt sie der Aiten deren Zauberstab, und begibt sich auf die Flucht mit inrem Liebsten Roland. Zuvor jedoch tropfelt sie drei Blutstropfen, die von dem ermordeten Haupt der leiblichen Tochter der Hexe stammen, auf die Erde, um die Hexe zu täuschen, indem sie am Morgen für das Mädchen antworten sollen. Auch hier verfolgt die Hexe die Kinder und kann nichts gegen die Zauberkräfte des Mädchens ausrichten. Als das Mädchen den Liebsten Roland in einen See und sich selbst in eine Ente verwandelt, mus die Hexe "apenas unverrichteter sache wleder umkenren." Beim zweiten versuch verwandelt das Madchen sich in eine Blume in einer Dornenhecke und den Liebsten Roland in einen Geigenspieler, der solange einen Zaubertanz spielt, bis sich die Hexe zu Tode getanzt hat.

Ähnlich dazu verläuft Bechsteins Märchen Vom Knaben, der das Hexen lernen wollte Diese Geschichte, wle auch schon Bechsteins Version von Hărisel und Gretel, Ist im Gegensatz zu den Grimmschen Erzählungen sehr viel anschaulicher und drastischer erzählt, und ist wahrscheinlich viel verantwortlicher für unser heutiges Hexenblld als die Märchen der Brüder Grimm. Deshalb bedarf dieses Märchen vielleicht besonderer Beachtung als Vertreter des Types Zaubermärchen. 


\section{Vom Knaben, der das Hexen lernen wollte}

1. Vorlage für dieses Märchen war eine Erzählung J. Mussäus', die 1840 unter dem Titel "Die Hexenkunst" in seinem Beitrag Mecklenburgische volksmärchen im fünften Band der Jahrbücher und Jahresberichte des Vereins für meck lenburgische Geschichte und Altertumskunde erschien. Ursprünglich war das Märchen ein "einf ach und geradezu nüchtern erzähltes Märchen, das Bechstein erheblich ausgebaut und lebendiger gestaltet hat nicht ohne gelegentlich ein wenig übers Ziel hinauszuschießen"22. Da eine Textvergleich hier nicht möglich ist, werde ich sofort zu Punkt drei übergehen.

3. In Vom Knaben, der das Hexen lernen wollte begegnen wir einem Jungen, der das Hexen lernen möchte, und deshalb in "einen dunklen Wald" geht, um einen Hexenlehrer zu finden. Dort kommt "ein uraltes Weiblein durch das Gebüsche gekrochen, das keinen Zahn mehr im Munde und schrecklich rote Augen hatte. Inr Rücken war gekrümmt, ihr Haar war weiß, und hing inr wild um den Kopf herum, und wehete im Winde." Sie nimmt den Jungen mit zu sich, wo er sich in Lieschen, ein hübsches, junges Mädchen das bei der Hexe wohnt, verliebt (und sie sich in inn). In der Hütte sind außerdem drei Kröten und "über dem niedern Herde hing ein Kessel, darinnen eine Brühe kochte, wie Gänseschwarz, Hasenpfeffer, oder sonstiges Schwarzsauer mit Fleischknöchlein darin." 23 Der Junge will nicht essen, da es inm vorkommt,

22 Walter Scherf in Bechstein, 854.

23 Dies ist die einzige Stelle in einem Märchen, wo die Zutaten zu einer Hexensuppe beschrieben werden. 
als ob die Knöchle in "Finger und Zehen von Kindern wären." Und tatsächlich faßt die Hexe Pläne, den Jungen am andern Tage zu schlachten. Lleschen tut er jedoch leid, und "es graute inr vor inr selbst, daß sie gezwungen war, der alten bösen Hexe zu dienen, die sie schon lange, als sie noch ein ganz kleines Kind war, ihren Eltern geraubt und in den tiefen wald geschleppt hatte, und hatte das Hexenwerk lernen müssen, wie man pfeilschnell durch die Luft eilt, wie man sich unsichtbar macht, wie man sich in andere Gestalten verwandelt". Lieschen ist also offensichtlich jemand, der der Hexe Widerstand leisten kann, und sie beschließt, zusammen mit dem Jungen zu fliehen. Auch hier, wie in Der Liebste Roland, benutzt Lieschen ein Hilfsmittel, hier Speichel, der "vermittelst eines Hexenzaubers, den Lieschen verübt" sprechen kann, um die Hexe hinzuhalten. Als die Hexe endlich die Flucht der beiden entdeckt, benutzt sie all inre Zauberkräfte, um sie einzuholen. "Sie ergriff einen Besenstiel, und rannte aus dem Hause. Sie schlug mit dem Besen an die Türe, da ward das Häuschen unsichtbar; sie trat auf einen Bovist, da wallte eine Wolke empor; sie setzte sich auf inren Besenstiel, und funr als Wolke in die Luft." Als sie die Kinder einholt, ist es jedoch Lieschen, die sich ans Zaubern macht. "Jetzt lasse mich meine Kunst brauchen. Ich will ein Dornstrauch werden, und dich als eine Schlehe tragen." Und seltsamerweise hat die Hexe keine Macht über Lieschen und kann die Beere nicht fassen. Und auch als Lieschen noch einmal zaubert ("da wurde plötzlich der Dornbusch zu einem Wasser, und die Beere zu einem kleinen Entrich, alles durch Lieschens Zauberkunst, die sie von der Alten gelernt hatte") bemüht sich die Hexe vergebens, etwas dagegen zu unternehmen. Ob sie inre Pantoffel in einen Raubvogel oder ein Krokodil verwandelt, der Entrich entkommt inr doch. Und als sie sich anschickt, den Teich leer zu 
trinken, verwandelt sich das Wasser in inrem Leib zu Feuer, und sie zerplatzt.

4. Es ist erstaunlich, wie hilflos in all diesen Märchen die Hexe, die anfangs meist als mächtige Zauber in beschrieben wurde, tatsächlich gegenüber der Heldin ist. In allen Fällen muß sie unverrichteter Dinge abziehn, Dis sie schlleßlich bei dem Versuch, sich inre Beute zu erhaschen einen schmählichen Tod findet. Erstaunlich ist auch, daß das Mädchen das Zaubern meist nicht wirklich gelernt hat, ja im Prinzip sogar ablehnt, und trotzdem die Hexe mühelos besiegt, wenn es darauf ankommt, sich und inren Llebsten zu retten. Die wirklich mächtigen Zauberinnen sind also nicht die Hexen, sondern die jungen Mädchen, die in Berührung mit den Hexen kommen. Und das Zaubern als solches scheint im Prinzip nicht verdammungswürdig , ja in einigen Fällen sogar wünschenswert zu sein. Die Entrüstung gilt vieimenr der Art und Weise, wie die Zauberkräfte eingesetzt werden. Die Botschaft hier scheint also zu heißen, wenn man die Hexenkunst für gute Zwecke verwendet, wird sie belohnt, wenn für böse Zwecke, mit dem Tod bestraft 


\section{DIE HEXE ALS GUTE UND BÖSE GESTALT}

In der Kategorie der Hexe als zugleich gute wie böse Gestalt finden wir die meisten überbleibsel aus vorchristlichen Zeiten und aus der Mythologie. Der Aspekt der lebensspendenden und zugleich todbringenden Urmutter ist das ältestete Symbol des natürlichen Zyklus der Erde, die Nahrung spendet und Tod bringt. Kein anderes Märchen bildet eine direktere Verbindung zwischen der Gestalt der Großen Göttin in der Mythologie und der Gestalt der Hexe/Weisen Frau in den Märchen als das der Frau Holle. Und so Ist das Märchen von der Frau Holle wohl auch eines der bekanntesten und bestimmt am weitesten verbreitet. Ob unter dem Namen Holda, Hulda, Perchta, Berchta oder wie auch immer, es gibt eine ähnliche Version des Märchens in fast allen Teilen der Welt, 24 besonders verbreitet ist es jedoch in dem deutschsprachigen Raum. Fast jede Gegend hat ihre eigene Version des Glaubens an die Gött in Holda, Hulda, Perchta, etc.25

Holdâ ist die freundliche, milde, gnädige gött in und frau ... Volkssagen und märchen lassen frau Holda (Hulda, Holle), Hulle, frau Holl) als ein höheres Wesen auftreten, das den menschen freundliche, hilfreiche Gesinnung beweist, und nur dann zürnt, wenn es unordnung im haushalt wahrnimmt. 26

\section{4 siehe Bolte, $207 \mathrm{ff}$.}

$25 \mathrm{v}$. Waschnitius schrieb ein ganzes Buch über die Erforschung des Glaubens an die Göttin unter dem deutschen Volk. Stehe Viktor Waschnitius, Perht. Holda und verwandte Gestalten (Wien: Alfred Hölder, 1913).

26 Jacob Grimm, Deutsche Mythologie, $220 \mathrm{ff}$. 
Ihr Bereich umspannt sowohl den Himmel (wenn es schneit, so macht sie ihr Bett), als auch die Erde (sie bringt dem Lande Fruchtbarkeit), und inr Aufenthaltsort ist das Wasser (man gelangt zu ihr durch einen Brunnen) Sie beauf sichtigt den Feldbau und den häuslichen Bereich und wird mit dem Spinnen und dem Flachs assoziiert. Halten sich die Frauen an inre Gebote, so werden sie reichlich belohnt. Sind sie jedoch faul, wollen nicht spinnen oder inre häusliche Arbeit verrichten, so werden sie bestraft. Holda wird also auch zur strafenden Richterin und in diesem Aspekt wird sie oft als böse Hexe gesehen.

Hieran knüpft sich, daß Hulda statt der göttlichen gestalt das aussehen einer hässlichen langnasigen, grosszahnigen alten mit struppigem, engverworrenem haar annimmt.27

In Frau Holle finden wir alle diese Aspekte der Göttin nur wenig geändert wieder.

\section{Frau Holle}

1. Das Märchen kommt nicht in der Ölenberger Handschrift vor, da die Brüder Grimm es erst 1811 von Dortchen Wild erzählt bekamen. Bolte glaubt, daß eine zweite Fassung von dem Pfarrer G.A.F. Goldmann stammt 28 , in den Anmerkungen von 1822 steht lediglich "aus Hessen und Westfalen"29. Eine dritte Version mit Namen Murmelthier, die sich auf das Pentamerone und

27 ebda, 223.

28 Bolte, 207.

$29 \mathrm{KHM}$, Band 3, 52. 
die Braunschweiger Sammlung bezieht, war Jacob Grimm jedoch schon 1812 bekannt 30

2. Die Veränderungen zwischen den Fassungen von 1812 und 1819 sind relativ geringfügig und unterscheiden sich nur darin, daß in der letzteren der Sturz in den Brunnen durch das Fallenlassen der Spindel erklart wird und die Madchen von einem Hann begrüßt werden

3. Wiederum wird die Handlung in der Geschichte von einer bösen Stiefmutter ausgelöst, die inre eigene Tochter, die häßlich und faul ist der schönen und fleiBigen Stief tochter vorzient. Als die Stieftochter beim Spinnen ihre blutige Spule unabsichtlich in den Brunnen fallen läßt, schickt die böse Stiefmutter sie unbarmherzig hinterher. So springt das Mädchen in den Brunnen und erwacht auf einer schönen Wiese. Die ersten zwei Merkmale, die inr begegnen, sind die Wahrzeichen der Frau Holle, die auch die Wahrzeichen der Göttin Holda sind, ein Backofen oder Herd als Zeichen des häuslichen Bereichs ${ }^{31}$ und ein Baum voll Äpfel, Früchte der Göttin32. Sie besteht die erste Prüfung onne zu wissen, daß es eine Prüfung ist, indem sie den Backofen seiner Brote entleert und die Äpfel vom Baum schüttelt. Sodann kommt das Mädchen zu einem kleinen Haus, "daraus guckte eine alte Frau, well sie aber so große Zähne hatte, ward inm angst, und es wollte fortlaufen"(KHM 24). Frau Holle überredet das Mädchen jedoch, bei inr $z U$ bleiben und ihr bei der Hausarbeit zu helfen. Sie sagt dem Mädchen genau,

30 Rölleke, 209.

31 siehe Robert Graves, The White Goddess and Sir Frazer's Golden Bough.

32 siehe Barbara Walker's Ihe Woman's Encyclooedia of Myths and Secrets (San Francisco: Harper \& Row, 1983). 
was von inr erwartet wird, und "dafür hatte es auch ein gut Leben bei ihr, kein böses Wort und alle Tage Gesottenens und Gebratenes." Als das Madchen Heimweh bekommt, entläßt Frau Holle sie ohne weiteres und läßt sie sogar über und über mit Gold bedeckt nach Hause ziehen. Neidisch auf das Glück der guten Schwester springt die böse Schwester auch in den Brunnen und begegnet denselben beiden Symbolen, dem Backofen und dem Apfelbaum sie besteht den Test jedoch nicht, indem sie die Brote verbrennen und die Äpfel verfaulen läßt. Auch bei Frau Holle erfüllt sie inre Pflicht nicht und wird schnellstens entlassen. Zum Lohn für ihre Pflichtvergessenheit wird sie mit Pech übergossen, das "solange sie lebte, nicht abgehen" wollte.

4. Die Rolle der Hexe in diesem Märchen erinnert stark an die von Hänsel und Gretel In beiden Märchen wartet die Hexe in ihrem Haus, bis jemand zu inr kommt und beidesmal tritt sie zunächst als nahrungsgebende Lebensspenderin auf. Auch die großen Zähne der Frau Holle erinnern an die menschenfressende Eigenschaft der Hänsel und Grete/-Hexe. Während sich die Hexe in Hänsel und Gretel jedoch tatsächlich als Menschenfresserin entpuppt, ist Frau Holle sowohl belonnende Spenderin als auch bestraf ende Richterin. Sie ist im Prinzip eine wohltätige Frau, die genau erklärt, was sie von einem verlangt und erwartet, und erst als das böse Mädchen diesen Erwartungen nicht entspricht und trotzdem belohnt werden möchte, zeigt Frau Holle ihre dunkle Seite. Sle erscheint als eine gerechte Gestalt, die fair handelt und fair richtet. Eine Parallele findet sich hier auch zu Rapunzel, wo die Zauberin dem Mädchen solange wohlgesonnen ist, wie dieses ihre Erwartungen erfüllt und nur inr dient. Auch inr Name, Frau Gothel, welst auf inre Verbindung zu der mythologischen Göttin hin, die sowohl belohnt, als auch straft. Erst als Rapunzel die Zauberin hintergeht, und inr inr Vernäitnis 
zu dem Prinzen verheimlicht, wird die Zauberin zur bösen Hexe, die das Mädchen bestraft und verstoßt. 


\section{DIE HEXE ALS WEISE FRAU/HELFERIN/GUTE FEE}

In der letzten Kategorie der weisen Frau/ Helferin/ Guten Fee unterscheiden wir zwischen der weisen Frau, die persönlich auf tritt und hilft und der weisen Frau, die tot ist und vom Jenseits aus hilft. Obwohl auch hier Zaubermittel benutzt werden, wird die Frau in Keinem Märchen als Hexe bezeichnet, sondern erhält den Namen weise Frau, Mütterchen, Alte, und Fee. Und obwohl sie in relativ vielen Märchen vorkommt, ist inre Rolle gering und hinterläßt wenig Eindruck, da sie im Gegensatz zu der bösen Hexe nicht mehr Katalysator und im Gegensatz zur bosen Stlefmutter nicht mehr Handlungsauslöser ist, sondern nur noch in Krisenfällen mit einer Gabe aushilft. Der toten Mutter, die aus dem Jenseits hilft, fallt eine Rolle zu in den Märchen Achenputtel (KHM21), Van dem Machandelooom (KHM 47), Der wacholderbaum (DMB 66) und Aschenorödel (DMB 62), während die weise Frau in den Märchen Die 6 Schwäne (KHM 49), Dornrosschen (KHM 50), Der Liebste Roland (KHM 56), Der Krautesel (KHM 122), Einäugle in. Zweiäuglein und Dreiäugle in (KHM1/30), Die zertanzten Schuhe (KHM /33) und der ursprünglichen version von der Erzählung Die weiße Braut und die schwarze Braut (KHM 135) vorkommt.

In all diesen Märchen verfügt die weise Frau über Zaubermittel, die sie zu Gunsten ihres Schützlings anwendet, und für die sie daher nicht bestraft wird, im Gegensatz zur bösen Hexe, die, wie wir gesehen haben, für ihre Zauberkräfte übel bestraft wird. Des weiteren wird sie hauptsächlich mit Natur und geheimem Wissen assozilert, was wiederum an die alten 
Priesterinnen der vorchristlichen Zeit mit inrem Heil-und Kräuterwissen und ihren Weissagungen erinnert.

Es ist e in bedeutsamer zug unseres heidenthums, dass zu diesem amt frauen und nicht männer auseriesen werden... Nach deutscher ansicht sche inen aussprüche des schicksals im munde der frauen grössere heiligkeit zu erlangen, weissagung und zauber in gutem wie bösem $\operatorname{sinn}$ sind vorzugsweise gabe der frauen, ...33

In Aschenputtel, Van dem Machandelboom und Einäuglein, Zweiäuglein und Dreiäugle in ist es jeweils ein Baum, der auf dem Grab der Mutter (bzw. auf dem Grab, in dem Zweiäugle in das Gedärm inrer zauberkundigen Ziege versteckt) wächst und der Heldin Hilfe bringt. In Dornröschen ist es eine gute Fee, die den Todeszauber der bösen Fee Dank ihrer Zaubermacht in einen langen Schlaf umwande In kann. In Der Liebste Roland of fenbart die weise Frau Roland, wie er eine Zauberblume in inre richtige Gestalt als Mädchen verwande In kann. In Die zertanzten Schuhe ist es eine alte Frau, die dem jungen Mann sagt, wie er herausf inden kann, wo die Prinzessinnen die Nacht über tanzen. Und in Einäuglein, Zweiäuglein und Dreiäugle in ist es die weise Frau, die Zweiäuglein den Spruch verrät, mit dem es immer genug zu essen haben wird. In Der Krautesel ist es ein "altes häßliches Mütterchen", das dem Helden sagt, wie er zu einem Wunschmantel und einem Zaubervogel gelangen kann.

Interessanterweise kommt die Hilfe für Mädchen weit häufiger indirekt von der toten Mutter und direkt in Form von Bäumen und Tieren, während die Hilfe für Jungen direkt von der weisen Frau und in Form von Ratschlägen kommt. In all diesen Märchen jedoch ist es nicht die weise Frau,

33 Jacob Grimm, Deutsche Mythologie, 329. 
die im Brennpunkt des Geschehens steht, sondern der Held, bzw. die Heldin. Im Gegensatz zur bösen Hexe ist die weise Frau zu unwichtig, als daß ihr Aussehen eingehend beschrieben würde Sie ist nur eine Frau, meist älter, die zufallig auftaucht und sofort nach erledigter Tat wieder verschwindet Sie hat nur ganz kurz Einfluß auf das Geschehen und bleibt dem Leser deshalb auch kaum im Gedächtnis. 


\section{SCHLUSSKAPITEL}

Abschließend möchte ich noch e inmal die Fragen stellen, die ich versucht habe, in meiner Arbeit zu beantworten und die Schlußfolgerungen, zu denen ich gekommen bin, zusammenfassen. Die erste Frage beschäftigte sich damit, warum man, wenn man nach Märchen gefragt wird, hauptsächlich und sofort an böse Hexen denkt? Und die Folgerung daraus fragte nach dem heutigen Hexenbild, das in den Köpfen der Märchenleser vorherrscht und einer möglichen historischen Verbindung zu vorchristlichen Frauengestalten in Wirklichkelt und in der Mythologie..

Zur ersten Frage wäre anzunehmen, daß der Grund für die Vorherrschaft des Hexenbildes vor allen anderen Märchencharakteren in der Häufigkeit, in der die Hexe im Märchen vorkommt und in der bösen Gestalt, in der sle erscheint, begründet liegt. Wie wir jedoch gesehen haben, befassen sich insgesamt nur etwa vierzehn Prozent aller Grimmschen Märchen und noch weniger der Märchen Bechsteins mit dem Vorkommen von bösen Hexen. Tatsächlich treten auch eine ganze Anzahl von Hexen in der Gestalt von weisen Frauen und gütigen Zauberinnen auf, und doch sind es die bösen Hexen, die im Gedächtnis bleiben. Über das Aussehen dieser Hexenfrauen in den Märchen wird so gut wie nie berichtet, und eigentlich nur Bechstein schlldert die böse Hexe in glühenden Farben. Es muß also noch andere Gründe für das starke Hexenbild geben, als die oben angeführten. 
Heinz Rölleke gibt in seinem Aufsatz über "Die Frau in den Märchen der Brüder Grimm"1 mögliche Ansätze, dieses Phänomen besser zu verstehen: Erstens einmal handelten in den Grimms Märchen der Kleinen Ausgabe, die 1825 erstmals veroffentlicht wurde, und die im 19. Jahrhundert

hauptsächlich als die Märchen der Brüder Grimm bekannt wurde, über fünfzig Prozent der Märchen von Frauengestalten. Zweitens sind viele dieser fünfzig Märchen die auch heute noch bekanntesten Märchen, und davon sind die meisten die sogenannten Zaubermärchen, die sich hauptsächlich mit dem Konflikt zwischen der Heldin und einer bösen Gegenspielerin befassen. $\mathrm{Zu}$ diesen bekanntesten und auch beliebtesten Märchen gehören u.a. Hänsel und Gretel, Dornröschen. Sneewittchen alles Märchen, in denen die Frau in böser Gestalt auftritt, einmal als böse Hexe, dann als böse Fee und schließlich als Döse Stiefmutter. Die restlichen Stücke, die aus Legenden, Schwänken, Sagen, usw. bestehen, sind den Zaubermärchen zwar numerisch überlegen, erreichten jedoch nie deren Beliebtheitsgrad.

Darüber, warum gerade die Märchen, in denen von Heldinnen und deren Gegenspielerinnen die Rede ist, den größten Beliebtheitsgrad erreicht haben, läßt sich nur spekulieren. Man darf jedoch nicht vergessen, daß die Märchen den Brüdern Grimm anfangs hauptsächlich von Frauen erzählt wurden, daß Geschichten of tmals von Frauen mündlich weitervererbt wurden, und daß die Märchen zu Zeiten der Brüder Grimm und Bechsteins hauptsächlich weiblichen Kindern erzählt wurden. Des weiteren wäre es möglich, in diesem Interesse an Märchen mit weiblichen Helden ein Überbleibsel zu sehen aus Zeiten, in denen Frauen starke Positionen einnahmen und magische

1 in Diefrau im Märchen, Hrsg. Sigrid Früh und Rainer Wehse (Kossel: Erich Röth Verlag, 1985). 
Funktionen erfüllten. Obwohl über die Jahrhunderte hinweg unterdrückt, bleibt die Erinnerung an weissagende, zauberkräftige Frauen doch stark genug im Volksbewußtsein, daß sie besonders auf Kinder noch immer eine geheime Faszination ausübt.

Die 2 weite Frage nach dem heutigen vorwiegend negativen Bild der Märchenhexe läßt sich aus verschiedenen Motiven heraus beantworten, aus der Verwandschaft von Mythologie mit Märchen, aus den geschichtlichen Ereignissen der Hexenverfolgung, aus den pädagogischen Absichten der Brüder Grimm und nicht zuletzt aus den Abbildungen, mit denen die Märchen geschmückt wurden und später besonders von Walt Disney anschaulich gemacht wurden.

Zunächst einmal besteht die Theorie, entwickelt von Sir James Frazer und anderen, daß Märchen mit Mythen verwandt sind. In Kapitel 3 habe ich versucht zu zeigen, daß das Bild der Märchenhexe unter anderem aus mythologischem Grundgut besteht, welches sich in verschiedenen Motiven, die in den Zaubermärchen ständig vorkommen, zeigt. So wohnt die Hexe, wie schon erwähnt, meistens in einer Hütte im wald, was einmal an das althochdeutsche wort hagazussa gleich waldweib erinnert 2 , und zum anderen an den alten germanischen Brauch der Götteranbetung im Freien, wobei Bäume einen heiligen Platz einnahmen und Frauen of tmals als Priesterinnen fungierten. 3 Eine weitere Verbindung zur Mythologie besteht

2 siehe etymologische Ausführungen in Kapitel 2.

3 siehe James Frazers The New Golden Bough (New York: S.G.Phillips, Inc., 1959), Robert Graves' The White Goddess (New York: Farrar, Straus and Giroux, 1948), Erich Neumanns Die Große Mutter (Princeton: Princeton Univ. Press, 1963) und Mer lin Stones When God Was a Woman (New York: Harcourt Brace Jovanovich, 1976), u.a. 
in den unzähligen Fruchtbarkeitssymbolen, die in den Märchen wiederkehren So finden wir den vorchristlichen Ritus der 'Heiligen Hochzeit', in der sich die Große Göt in mit einem irdischen Mann verheiratet und ihn dann symbolisch für das Wohl der Ernte opfert, um alle inre Schützlinge nähren zu können, in der menschenfressenden Hexe wieder, die Jungen mästet mit der Absicht, aus innen für sich und ihre Tochter Nahrung zu gewinnen. Die Hexe als Nahrurigsspenderin ist ein Motiv, das in positiver Art und weise auch in Frau Holle und anfangs in Hänsel und Gretel erscheint. Desweiteren werden Äpfel, die in der Mythologie als lebensspendende Frucht der Großen Göttin angesehen werden ${ }^{4}$, in den Märchen sowohl als nährende (Frau Holle) als auch als tötende Frucht (Sneewittchen) verwendet. Vögel in der Mythologie sind Begleiter der Großen Göttin, die als Boten fungieren und zwischen den Welten hin und herfliegen. In vielen Märchen sind es Vögel, haupsächlich Tauben, die den Heldinnen und Helden vorausfliegen, um innen den Weg zu zeigen (Die Alte im Wald. Hänsel und Gretel) oder die ihnen auf andere Art und Weise behilflich sind (Aschenputtel). Noch viel mehr könnte über die Verbindung 2 wischen Mythologie und Märchen gesagt werden. Ich möchte als letztes Belspiel jedoch nur noch das Vorkommen von Wasser erwähnen. In Grimm's Bad Girls and Bold Boys widmet Ruth Bottigheimer ein ganzes Kapitel der Assoziation zwischen Wasser und Frauen und Fever und Männerns. In der Mythologie werden Wasser und Erde als Elemente der Großen Göttin gesehen. Zugang zu inr wird durch einen Brunnen oder Teich erlangt, Wiedergeburt wird durch wasser symbolisiert und Wasservögel wie Z.B. die Ente sind ihr heilig. In den Märchen kommen Goldmarie und Pechmarie zu

\footnotetext{
4 siehe Barbara Walker. The Woman's Encyclopedia of Myths and Secrets (San Francisco: Haprer \& Row, 1983).
} 
Frau Holle, in dem sie in einen Brunnen fallen. In vielen anderen Märchen rettet sich das Mädchen vor der Verfolgung durch die Hexe, indem sle sich in eine Ente verwandelt (Der Liebste Roland, Fundevogel u.a.), und in Hänsel und Gretel führt eine Ente die Kinder über den Teich. Wasser ist auch oft die Todesursache in Märchen, sei es, daß die böse Hexe einen Teich aussauft und dabei zerplatzt (Fundevogel, vom Knaben, der das Hexen lernen wollte), sei es, daß die arme Stief tochter ins wasser gestoßen und getotet wird CDie weiBe und die schwarze Braut, Brüderchen und Schwesterchen! Noch viele andere Beispiele wären zu erwähnen, doch ist das wohl das Material zu einer neuen Arbeit und hier nicht möglich.

Ein weiterer Baustein für das heutige Hexenbild findet sich onne Zwelfel in den Ereignissen der Hexenverfolgung des Mittelalters. Obwohl es schon zu allen Zeiten zauberkundige Menschen gegeben hat, fällt in vorchristlichen Zeiten diese Rolle hauptsächlich Priesterinnen, Priestern und weisen Frauen zu. Ihre Zauberkundigkeit scheint sich hauptächlich auf natürliche Phänomene wie Geburten, das Heflen von Krankheiten und das Vorhersagen von Wetterveränderungen zu beziehen. Diesen Heilern wurde vom Volk sowonl Respekt als auch Furcht entgegengebracht, da sle Macht über die wichtigsten Funktionen des Lebens, über Geburt und Tod, hatten. Erst nach dem 13. Jahrhundert, mit der fortschreitenden Christianisierung der westlichen Welt, wird das Wort 'Hexe' mit dem Teufel, der eine Erfindung des Christentums ist, und somit mit ausschließlich negativen Attributen assozilert. Wie ich gezeigt habe, läßt sich der Ursprung des modernen Wortes 'Hexe', hagazussa, auf die Bedeutung 'Waldweib' oder 'Hainweib' im Sinne von weiser Frau, die als Priesterin und Heilerin fungiert, 
zurückführen6 . Erst ab dem 13. Jahrhundert und mit dem Beginn der Hexenvertorgung wird aas bila der Hexe a1s Dose Frau, die mit dem Teutel im Bund Übles treibt und inre Zauberkräfte ausschließlich zum Schaden inrer Umwelt benutzt, zum allgemein verbreiteten und akzeptierten Begriff. Mit der Veröffentlichung des Hexenhammers 1486 wird die Hexe zum ersten Mal zu einem Typus, der kategorisiert werden kann und der ganz bestimmte Eigenschaften, Zauberkünste und-mittel vorzuweisen hat Von dieser zeit an, bis zu den letzten Hexenverfolgungen im 18 Jahrhundert, kristallisiert sich im Volksbewußtse in ein immer genaueres Hexenbild heraus, zusammengetragen aus tatsächlichen Erelgnissen, Spekulationen hinter vorgehaltener Hand, Ausgeburten der Phantasie und schlichten Wunschvorstellungen, sodaß zu der zeit, in der die Brüder Grimm ihre Märchen sammelten, schon ein eindeutig einseitiges, nur negatives, Bild der Hexe entstanden war.

Die Brüder Grimm taten nun das inre, in inren Märchen das Bild der Hexe als einer bösen Frau aufrechtzuerhalten. Da sie neben inrem literarischen Anspruch, die Poesie des Volkes zu erhalten, auch ein pädagogisches Sendungsbewußtse in hatten, floß in die Textveränderungen, die sie zwischen dem ersten Aufschreiben der Erzählungen und der endgültigen Fassung von 1857 vornahmen, unbewußt eine weitere Verfestigung der unterschiedlichen männlichen und weiblichen Märchenrollen, und besonders eine weitere Verfestigung des heutigen Hexenbildes. Ob die Brüder Grimm die Märchen absichtlich oder unabsichtlich

6 siehe dazu auch "vroed" im altgermanischen frôd = Willen, Yerstand, woraus das neunieder ländische "vroed vrouw" = weise Frau (Hebamme) abgeleitet wird, aus dem Französischen "sage-femme" übersetzt in J.de Vries, Etymologisch Woordenboek.

(Utrecht/Antwerpen: Aula, 1967). 
zum Nachtell der Frauenrollen veränderten, ist im Endeffekt unwichtig, da dies die Art und Weise, in der sie gelesen und verstanden werden, nicht beeinträchtigt. Wie ich in Kapitel 3 gezeigt habe, tendiert das Bild der bosen Hexe, bzw. Stiefmutter dazu, immer negativer zu werden, während die weisen Frauen und guten Helferinnen kaum erwähnt werden. Die bösen Männer, wenn sie in menschlicher Gestait erscheinen, gehen straffrei aus, während die bösen Frauen ausnahmslos mit dem Tod betraft werden.

Eine genauere Beschreibung des Aussehens der Märchenhexe, wie wir sie uns heutzutage vorstellen, verdanken wir Bechstein, der sich, wie gesagt, viel mehr als Künstler und Schriftsteller sah, als die Brüder Grimm. In seinen Schilderungen wird die Hexe Dis ins kleinste Detail beschrieben, und bel inm finden wir die typischen Hexenmerkmale wie den Besen, den Kochtopf über dem Feuer und den Hexenbuckel vor.

Des weiteren tragen zu unserem heutigen Hexenbild bestimmt auch die Zeichnungen, die die Märchen sowohl in den Ausgaben der Brüder Grimm, aber noch mehr in Bechsteins Edition begleiteten, bei. Schon von Anfang an werden die Hexen in den Kinder- und Hausmärchen der Brüder Grimm mit einer Hakennase, gekrümmt mit einem Buckel und in der Hand einen Stock, dargestellt. Am weitaus berühmtesten und auch heute noch bekanntesten jedoch sind die Zeichnungen Ludwig Richters, die zwar heute mit den Märchen der Brüder Grimm in Verbindung gebracht werden, ursprünglich Jedoch für die Märchensammlung Bechsteins konzipiert wurden und auch in seinem Deutschen Märchenbuch erschienen. Dort, zusammen mit der Beschreibung Bechsteins, entsteht ein Bild der alten Frau, das einen wahrhaft das Fürchten lehren könnte. 


\section{SCHLUSSFOLGERUNG}

Ich habe mit meiner Arbeit zu zeigen versucht, wie verschiedene, hauptsächlich historisch bedingte Faktoren zusammengewirkt haben, um das vorwiegend negative Bild der Hexe, wie es uns in Marchen begegnet, zu zeichnen. Des weiteren habe ich versucht, eine verbindung zwischen den Zauberinnen der vor-christlichen Zeit und den Hexen der Märchen herzustellen. Auf dieser Verbindung aufbauend scheint es mir nicht verwunderlich, daß noch viele Züge dieser Zauberinnen in den Märchen nicht nur in den Charakteristiken der Hexen, sondern auch in den Mädchen, die mit Hexen in Berührung kommen, auftreten. Somit ließe sich vielleicht erklären, warum $Z$. B. in den Verfolgungsmärchen die jungen Mädchen sich und ihre Begleiter wie ganz selbstverständig durch Zauberei vor der Hexe schützen und dafür nicht bestraft werden, wăhrend die bösen Hexen immer mit dem Tod bezahlen müssen. In vor-christlichen Zelten wurde, wle in Kapitel 2 erläutert, Zauberei als ein natürliches und sowohl positives als auch negatives Phänomen betrachtet. Das Wissen der Brüder Grimm über altheidnische Brauche und Mythen war so groß, daß sich in inren Märchen erzieherische Absichten und bewußte Textabänderungen mit altheidnischen Überblelbseln und mythologischem Gut vereinigen und zu einem kuriosen Bild der Hexe vermischen.

Zum Abschluß sel erwähnt, daß die Hexe ein durchaus wichtiger Bestandteil der Märchen ist, mit dem viele Kinder zu einem denkbar frühesten Zeltpunkt in Berührung kommen. Da sie als eine vorwlegend 
negative, böse Gestait, vor der man sich in Acht nehmen muß, die Kinder frißt, Menschen verzaubert und innen allgemein Böses will, porträtiert wird, ist sie eine Figur, mit der sich das kind auf keinen Fall identifizieren will. Für den Jungen laßßt das noch genug andere figuren übrig, an deren Rollen er sich messen kann. Doch für das Mädchen bleiben nur noch die Mädchen und Prinzessinnen der Märchen, und die sind haufig passiv und unselbständig. Während diese Rollenverteilung zu Grimms und Bechsteins Zeiten vielleicht durchaus wünschenswert war, bedarf sie heutzutage gewiss einer Überprüfung und eines Umdenkens im Sinne einer gleicheren Verteilung der aktiven und passiven Rollen. Deshalb verdienen die Märchen, in denen Madchen als aktive Heldinnen porträtiert werden, wie z.B. in Fundevogel, Der Liebste Roland, Vom Knaben, der das Hexen lernen wollte u.a., durchaus eine größere Leserschaft. Auch wird es an der Zeit, die alte frau in einer positiveren Rolle zu zeigen, um auch diesen Aspekt des Lebens Mädchen zugängig zu machen. Da das Schreckelement eines Märchens für den Handlungsablauf jedoch durchaus wichtig ist, plädiere ich hier nicht etwa für die Abschaffung der Hexe, sondern im Gegentell für eine Erweiterung dieser Rolle auf das männliche Geschlecht in einem größeren Maße, als bisher geschehen.

Erst wenn geschlechtsspezifische Unterschiede in Märchen aufgehoben sind, kann die Handlung eines Märchens einen elgenständigen Wert im Sinne Bettelneims erhalten.

Es besteht kein Zwelfel an dem Verdienst der Brüder Grimm und Bechsteins um ein Kulturgut, das eine neue Gattung eingeführt hat, und ohne das die Literatur ein großes Stück ärmer wäre. Da sich jedoch Literatur im Laufe der Zeit ändert, sehe ich keinen Grund, warum Märchen, die heutzutage 
herausgegeben und verbreitet werden, nicht für Leser des 20. Jahrhunderts geändert und modernisiert werden können 


\section{Primaliteratur}

Bechstein, Luawig Samuluche Märchen. Munchen Winkler, 1983

Grimm, Jacob L K Deutsche Mythologlen 3 Bande Darmstadt Wissenschaftliche Buchgesellschaft, 1965

Grimm, Jacob und Wilhelm, Hrsg. Deutsche Sagen Mürchen. Winkler-Verlag, 1956.

---, Kinder- und Hausmarchen Gesammelt von den Brüdern Grimm. Einl von Herman Grimm. Vollstandige Ausgabe. München: Winkler Verlag, 1063

---, Kinder-und Hausmarchen 3 Bande Stuttgart: Philip Reclam Jun., 1983

The Complete Fairy Tales of the Brothers Grimm. Ed. Jack Zipes. New York. Bantam Books, 1987. 
Sekuridarliteratur

Aarne, Antti Amatus Ihe Types of the Folktale A Classification and Bibliograohy Transl. Stith Thompson. 2d revision. Helsinki: Suomalainen Tiedeakatemia, 1961.

Aron, Albert W. Iraces of Matrlarchy in Germanc Herulore. Madison: Univ. of Wisconsin, 1920.

Bachofen, Johann a. Myth, Bellgion, and Mother-Right, Princeton: Princeton Univ. Press, 1967.

Baroja, Julio Caro. The World of the Witches TransI. O.N.V Glendinning Chicago: Univ. of Chicago Press, 1965.

Beauvolt, Simone de. Ihe Second Sex New York, Knopf, 1952.

Becker, Gabriele, silvia Bovenschen, Hèlmut Brackert ua. Aus der Zeit der verzwelflung - zur Genese und Aktualit at des Hexenbildes. Frankfurt/Main: n.a., 1977).

Beit, Hedwig von. Symbolik des Märchens. 3 Bände. Bern: Francke Verlag, 1956-57.

Bell, Marilyn J. "Feminist Spirituality: Bags, Hags, and Crones." Besources for Feminist Research/Documentation sur la Recherche Feministe 11.3 (July 1982): 223-24.

Bettelheim, Bruno. Ihe Uses of Enchantment: the Meaning and Importance of Fairy Tales. New York: Knopf, 1976.

Bledermann, Hans. Handlexikon der magischen Künste. Dritte verbesserte und wesentlich vermenrte Auflage. Graz-Austria: Akademische Druckund Verlagsanstalt, 1986. 
Bolte, Johannes und George Polivka. Anmerkungen zu den "Kinder- und Hausmärchen". Fünf Bände 1913-32. Hildesheim: Georg Olms, 1963.

Bottigheimer, Ruth B., ed. Fairy Tales and Society: Illusion, Allusion and Paradigm. Philadelphia: University of Pennsylvania Press, 1986

---, Grimms' Bad Girls and Bold Boys. The Moral \& Social Vision of the Tales New Haven: Yale University Press, 1987.

---, " 'Still Gretel!' - Verstummte Frauen in Grimms 'Kinder-und Hausmärchen' ." Kontroversen, alte und neue: Akten des VII. Internationalen Germanisten-Kongresses, Göttingen 1985. Hrsg. von Albrecht Schöne. Tübingen: Niemeyer Verlag, 1986.

---, "Tale Spinners: Submerged Voices in Grimm's Fairy Tales." New German Critjque 27 Fall 1982: 141-150.

---, "The Transformed Queen: A Search for the Origin of Negative Female Archetypes in Grimm's Fairy Tales." Amsterdamer Beiträge zur Neveren Germanistik $10(1980): 1-12$.

Bovenschen, Silvia. "The Contemporary Witch, the Historical Witch and the witch Myth." New German Critique 15 Fall 1978: 83-119.

Bracker, Helmut, Hrsg. Und wenn sie nicht gestorben sind... Perspektiven auf das Märchen. Frankfurt a.M.: Suhrkamp Verlag, 1982

Campbell, Joseph. The Hero with a Thousand Faces. Princeton: Princeton University Press, 1949.

---, The Masks of God. New York: Viking Press, 1959.

Coff in, Tristam P. The Female Hero in Folklore and Legend. New York: Seabury Press, 1975.

Cox, George W. An Introduction to the Science of Comparative Mythology and Eolklore. 2d ed. London: K. PAul Trench, 1883. Singing Tree Press, 1968.

Dahl, Jürgen. Nachtfrauen und Geisterweiber: eine Naturgeschichte der Hexe. Ebenhausen bei München: Langew iesche Brandt, 1960. 
Davidson, HIlda R. Gods and Myths of Northern Europe Baltimore: Penguin Books, 1964.

Degh, Linda. "Grimm's Household Tales and Its Place in the Household: The Social Relevance of a Controversial Classic." Eairy Tales as Ways of Knowing. Ed. Michael M. Metger and Katharina Mommsen. Bern: Peter Lang, Inc., 1981.

Der große Duden. Etymologie Herkunftswörterbuch der deutschen Sprache. Band 7. Bearb. von der Dudenreaktion unter Leitung von Paul Grebe. Mannheim: Bibliographisches Institut, 1963.

Duerr, Hans Peter. Dreamtime: Concerning the Boundary Between Wilderness and Civilization. Trans. Felicitas Goodman. New York: Basil Blackwell Inc., 1985.

Eastman, Mary H. Index to Fairy Tales, Myths, and Legends, Boston: F. W. Faxon C0., 1926.

Eckstein - Diener, Berta. Mothers and Amazons. New York: Julian Press, 1965.

Ehrenreich, Barbara and Deidre English. Witches, Midwives, and Nurses. New York: The Feminist Press, 1973.

Ellis, John. One Fairy Story too Many. Chicago: Univ. of Chicago Press, 1983.

Frazer, Sir James. Ine New Golden Bough. New York: S. G. Phillips, Inc., 1959.

Früh, Sigrid, Hrsg. Märchen von Hexen und Weisen Frauen. Frankfurt a.M: Fischer, 1986.

Früh, Sigrid und Rainer Wehse, Hrsg. Die Frau im Märchen. Kassel: Erich Roth Verlag, 1985.

Garrett, Clarke. "Women and Witches: Patterns of Analysis." Signs 3 (1977): $461-70$.

Gimbutas, Marija. The Goddesses and Gods of Old Europe, 6500 to 3500 B.C. Berkeley: Univ. of California Press, 1982. 
Girardot, N. J. "Initiation and Meaning in the Tale of Snow white and the Seven Dwarfs." Journal of American Foklore. 90 (1977): 273-300.

Göttner-Abendroth, Heide. Die Göttin und inr Heros. München:

Fravenoffensive, 1980.

---, Matriarchal Mythology in Former Times and Today. Freedom: The Crossing Press, 1987.

Goheen, Jutta. "From the Brothers Grimm to Alice Schwarzer." German Studies Review 7 (1981): 381-387.

Graves, Robert. The White Goddess. New York: Farrar, Strauss and Giroux, 1966.

Handwörterbuch des Deutschen Aberglaubens. Hrsg. Hanns Bächtold-Stäubli. Berlin: Walter de Gruyter \& C0., 1930/31.

Heiligendorff, Wolf gang. Der keltische Matronenkultus und seine 'Fortentwicklung' im deutschen Mythos. Leipzig: H. Eichblatt, 1934.

Heinsohn, Gunnar and Otto Steiger. "The Elimination of Medieval Birth Control and the Witchcraft Trials of Modern Times." International Jeurnal of Women Studjes $5(3), 1982$.

Herzog, Rudolf. Germaniens Götter. Leipzig: Quelle \& Meyer, 1933.

Hexen. Katalog zur Wanderausstellung "Hexen" aus dem Hamburg. Museum für Völkerkunde. Hrsg. Thomas Hauschild. Berlin: Zerling, 1986.

Hillman, James. ed. Facing the Gods. Dallas: Spring Publications, 1980.

Horsley, Ritta Jo and Richard A. Horsley. "On the Trial of the 'Witches': Wise Women, Midwives and the European Witch Hunt." 1963. Women in German Yearbook. Ed. Marianne Burkhard and Edith Waldstein. Lanham: University Press of America, 1986.

Janning, Jürgen, Heino Gehrts, Herbert Ossowski, Dietrich Thyen, eds. Gott im Märchen. Band 2. Kassel: Erich Röth Verlag, 1982.

---, Vom Menschenbild im Märchen Band 1. Veröf fentlichungen der Europäischen Märchengeselischaft, 1980 
Jilg, Waltraut. "Der Begriff "Hexe" und seine Komplexität." Teufelsglaube und Hexenprozesse. Hrsg. Georg Schwaiger. München: Beck, 1987.

Jordan, Rosan A. and F. A. De Caro. "Women and the Study of Folklore." Signs 11.3 Spring 1986: 500-518.

Jordan, Susan. "Witch, Virgin, Hag and Crone." New Women's Times 7.9. October 1981: 14-17.

Just in, Dena. "From Mother Goddess to Dishwasher." Natural History 82.2. February 1973: 40-45.

Kauffmann, Friedrich. Deutsche Mythologie. Leipzig: G. J. Göschen, 1900.

Karlinger, Fellx. Grundzüge einer Geschichte des Märchens im deutschen Sorachraum. Darmstadt: Wissenschaf tliche Buchgesellschaft, 1983.

Kluge, Friedrich. Etymologisches Wörterbuch. Walter de Gruyter \& Co, 1967

Krippendorff, Klaus. Content Analysis: An Introduction to Its Methodology. Beverly Hills, Sage, 1980.

Lederer, Wolfgang. The Fear of Women. New York: Harcourt, Brace, Jovanovich, 1968.

Lehner, Ernst and Johanna. Picture Book of Devils. Demons and Witchcraft New York: Dover Publications, 1971.

Lexer, Matthias. Mittelhochdeutsches Handwörterbuch. Stuttgart: S. Hirzel Verlag, 1974.

Leyen, Friedrich von der. Das deutsche Märchen und die Brüder Grimm. Düsseldorf-Köln: Eugen Diederichs Verlag, 1964.

Lieberman, Marcia R. "'Some Day my Prince Will Come': Female Acculturation Through the Fairy Tales." College English 34 (1972): 383-395.

Linke, Werner. Das Stiefmuttermotiv im Märchen der germanischen Völker. Berlin: Ebering, 1933.

Lüthi, Max. Es war einmal. Vom Wesen des Volksmärchen Göttingen: Vandenhoeck \& Ruprecht, 1968 
---, Märchen Stuttgart: Metzler, 1962.

---, Das europäische Volksmärchen. Form und Wesen. Bern: Francke, 1960.

Lurie, Alison. "Fairy Tales for a Liberated Age." Horizon (July 1977): 80-5.

---, "Fairy Tale Liberation." New York Review of Books 17 Dec. 1970: 4244.

Lyons, Heather. "Some Second Thoughts on Sexism in Fairy Tales." Literature and Learning. Ed. Elizabeth Grugeon and Peter Walden. London: Open University Press, 1978.

Mannhardt, Wilhelm. Wald-und Feldkulte. Zweiter Band. Berlin: Verlag von Gebrüder Borntraeger, 1905.

Meyer, Elard H. Deutsche Volkskunde Berlin: Vereinigung wissenschaftlicher Verleger, 1921.

Michelet, Jules. Die Hexe. Deutsche Ausgabe. Leipzig: n.a., 1863.

Moore, Robert. "From Rags to Witches: Stereotypes, Distortions and Antihumanism in Fairy Tales." Interracial Books for Children 6 (1975): $1-3$.

Motz, Lotte. "The Winter Goddess: Percht, Holda, and Related Figures." Folklore: Journal of the Folk lore Society 95.2. (1984): 151-66.

Mudrak, Edmund, ed. Deutsche Heldensagen. Reutlingen: Ensslin \& Laiblin Verlag, 0. J.

Müller, Elisabeth. Das Bild der Frav im Märchen. München: Profil-Verlag, 1986.

Neumann, Erich. The Great Mother. Princeton: Princeton Univ. Press, 1963.

Newall, Venetia, ed. Ine witch Floure. Boston: Routledge and Kegan Paul, 1973.

Pagels, Elaine $\mathrm{H}$. "What Became of God the Mother? Conflicting Images of God in Early Christianity." Sions 2.2 Winter 1976: 293-303. 
Pearson, Karl. "Woman as Witch" of The Chances of Death, and Other Studies in Evolution. Vol. 2. London; New York: E. Arnold, 1897.

Petersen, E. "Die drelgestaltige Hekate." Archäologisch-epigraphische Mitteilungen aus Österreich. Vol. 4, 1880.

Phelps, Ethel $J$. The Maid of the North. Feminist Folktales from Around the World New York: Holt, Rinehart \& Winston, 1981.

Propp, Vladimir. Morphology of the Folktale. Trans. Laurence Scott. Austin: University of Texas Press, 1968.

Robbins, Rossell Hope. The Encyclopedia of Witchcraft and Demonology. New York: Crown Publishers, Inc., 1959.

Röhrich, Lutz. Märchen und Wirklichkeit. Wiesbaden: Franza Steiner, 1974.

Rölleke, Heinz, ed. Die älteste Märchensammlung der Brüder Grimm. Cologny - Geneve: Foundation Martin Bodmer, 1975.

--- Die Märchen der Brüder Grimm. München: Artemis Verlag, 1985.

--- Wo das Wünschen noch geholfen hat. Bonn: Bouvier Verlag Herbert Grundmann, 1984.

Rowe, Karen E. "Feminism and Fairy Tales." Women Studies 6.3. (1979): 237-257.

Rumpf, Marianne. Ursprung und Entstehung von Warn- und Schreckmärchen FFC 160. Helsinki: Suomalainen Tiedeakatemia, 1955.

Russell, Jeffrey B. A History of witcheraft. New York: Thames \& Hudson Inc., 1980.

Sautman, Francesca. "Woman as Birth -and-Death-Giver in Folk Tradition: A Cross-Cultural Perspective." Women Studies 12.3. (1986): 214-239.

Scherf, Walter. Lexikon der Zaubermärchen. Stuttgart: Alfred Kröner, 1982.

Schneider, Rolf-Rüdiger. Bechsteins Deutsches Märchenbuch. Wuppertal: Gesamthochschule, Fachbereich Sprach-LIt.wissenschaft, Dissertation, 1980. 
Schrader, Richard J. God's Handiwork. Images of Women in Early Germanic Literature. Westport, Connecticut: Greenwood Press, 1983.

Segel, Elizabeth. "Feminists and Fairy Tales." School Library Journal. (January 1983): 30-1.

Die Edda, die ältere und jüngere nebst den mythischen Erzählungen der Skalda. Übersetzt und hrsg. von Karl Simrock. Stuttgart: J. G. Cotta, 1851.

Sjoo, Monica and Barbara Mor. The Great Cosmic Mother. San Francisco: Harper \& Row, 1987.

(Sprenger, Johann und) Heinrich Institoris. Malleus Maleficarum. Der Hexenhammer 1487. Transl. J.W. Schmidt. Berlin 1906, Rpt. Darmstadt, 1974.

Starhawk. Ine Spiral Dance. San Francisco: Harper \& Row, 1979.

---, Iruth or Dare. Harper \& Row, 1987

Stone, Kay F. "Feminist Approaches to the interpretation of Fairy Tales." Fairy Tales and Society. Ed. Ruth Bottigheimer. Philadelphia: Univ. of Pennsylvania Press, 1986.

---, "The Misuses of Enchantment: Controversies on the Significance of Fairy Tales." Women's Folklore, Women's Culture. Ed. Rosan A. Jordan and Susan J. Kalcik. Philadelphia. Univ. of Pennsylvania Press, 1985.

---, "Things Walt Disney Never Told Us." Women and Folklore Ed. Claire R. Farrer. Austin: University of Texas Press, 1975.

Stone, Merlin. Anclent Mirrors of Womanhood Boston: Beacon Press, 1984.

---, When God Was a Woman. New York: Harcourt Brace Jovanovich, 1976.

Strich, Fritz. Die Mythologie in der deutschen Literatur. Band 2. Tübingen: Max Niemeyer Verlag, 1970.

Tatar, Marla. "Folkloristic Phantasies: Grimm's Fairy Tales and Freud's Family Romance." Eairy Tales as Ways of Knowing. Ed. Michael M. Metzger and Katharina Mommsen. Bern: Peter Lang, Inc., 1981. 
Irübners Deutsches wörterbuch. Hsg. Alfred Goße. Drei Bände. Berlin: Walter de Gruyter \& Co., 1939.

Vries, J. de. Etymologisch Woordenboek. Utrecht/Antwerpen: Aula, 1967.

Waelti-Walters, Jennifer. Fairy Tales and the Female Imagination. Montreal: Eden Press, 1982.

Walker, Barbara. The Woman's Encyclopedia of Myths and Secrets. San Francisco: Harper \& Row, 1983.

Waschnitius, Viktor. Penrt, Holda und verwandte Gestalten. Wien: Alfred Holder, 1913.

Weber-Kellermann, Ingeborg. Fravenleben im 19. Jahrhundert. München: Beck, 1983.

Weigele, Marta Spiders \& Spinsters. Albuquerque: Univ. of Mexico Press, 1982.

Willard, Nancy. "Goddess in the Belfry." Parabola 6.3. Summer 1981: 90-94.

Zipes, Jack. Don't Bet on the Prince. New York: Methuen, 1986.

---, Fairy Tales and the Art of Subversion. New York: Wildman Press, 1983.

---, The Trials and Tribulations of Little Red Riding Hood. South Hadley: Bergin \& Garvey Publishers, 1983. 